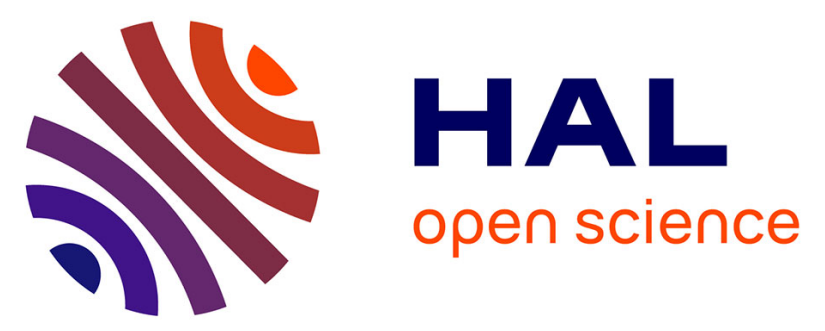

\title{
A Psychometric Analysis Update of Behavioral Pain Assessment Tools for Noncommunicative, Critically Ill Adults
}

Céline Gélinas, Aaron Joffe, Paul Szumita, Jean-François Payen, Mélanie Bérubé, Shiva T. Shahiri, Madalina Boitor, Gerald Chanques, Kathleen Puntillo

\section{To cite this version:}

Céline Gélinas, Aaron Joffe, Paul Szumita, Jean-François Payen, Mélanie Bérubé, et al.. A Psychometric Analysis Update of Behavioral Pain Assessment Tools for Noncommunicative, Critically Ill Adults. AACN Advanced Critical Care, 2019, 30 (4), pp.365-387. 10.4037/aacnacc2019952 . hal-02444795

\section{HAL Id: hal-02444795 \\ https://hal.science/hal-02444795}

Submitted on 6 Aug 2021

HAL is a multi-disciplinary open access archive for the deposit and dissemination of scientific research documents, whether they are published or not. The documents may come from teaching and research institutions in France or abroad, or from public or private research centers.
L'archive ouverte pluridisciplinaire HAL, est destinée au dépôt et à la diffusion de documents scientifiques de niveau recherche, publiés ou non, émanant des établissements d'enseignement et de recherche français ou étrangers, des laboratoires publics ou privés. 


\title{
A Psychometric Analysis Update of Behavioral Pain Assessment Tools for Noncommunicative, Critically Ill Adults
}

\author{
Céline Gélinas, PhD, RN $\{A 01\}$ \\ Aaron M. Joffe, Do \\ Paul M. Szumita, PharmD \{AO2\} \\ Jean-Francois Payen, PhD, MD \\ Mélanie Bérubé, PhD, RN \\ Shiva T. Shahiri, MScA, RN \\ Madalina Boitor, PhD \\ Gerald Chanques, $\mathrm{PhD}, \mathrm{MD}$ \\ Kathleen A. Puntillo, PhD, RN \{AO3\}
}

\section{ABSTRACT}

This is an updated, comprehensive review of the psychometric properties of behavioral pain assessment tools for use with noncommunicative, critically ill adults. Articles were searched in 5 health databases. A total of 106 articles were analyzed, including 54 recently published papers. \{AQ4\} Nine behavioral pain assessment tools developed for noncommunicative critically ill adults and 4 tools developed for other noncommunicative populations were included. $\{$ AO5 $\}$ The scale development process, reliability, validity, feasibility, and clinical utility were analyzed using a 0 to 20 scoring system, and quality of evidence was also evaluated. The Behavioral Pain Scale, the Behavioral Pain Scale-Nonintubated, and the Critical-Care Pain Observation Tool remain the tools with the strongest psychometric properties, with validation testing having been conducted in multiple countries and various languages. \{AQ6\} Other tools may be good alternatives, but additional research on them is necessary.

Key words: adult intensive care, behavioral scale, pain assessment, reliability, validity ain assessment is the first essential step to adequate pain management. In the intensive care unit (ICU), pain is highly prevalent while the patient is at rest and during procedures. ${ }^{1,2}$ Assessing pain is a daily

Céline Gélinas is Associate Professor, Ingram School of Nursing, McGill University, 680 Sherbrooke West, Room 1838, Montréal, Québec, Canada, H3A 2M7; and XXX, Centre for Nursing Research and Lady Davis Institute, Jewish General Hospital, Montréal, Québec, Canada (celine.gelinas@mcgill.ca).

Aaron M. Joffe is XXX, Department of Anesthesiology and Pain Medicine, University of Washington, Seattle, Washington. $\{$ AQ7\}

Paul M. Szumita is XXX, Department of Pharmacy Services, Brigham and Women's Hospital, Boston, Massachusetts.

Jean-Francois Payen is XXX, Department of Anesthesiology and Critical Care, and XXX, Inserm, U1216, Grenoble Institut Neurosciences, Grenoble Alpes University Hospital, Grenoble, France.

Mélanie Bérubé is $X X X$, Faculty of Nursing, Université Laval; and XXX, CHU de Québec, Université Laval Research Center (Hôpital de l'Enfant-Jésus), Québec City, Québec,

Canada.

Shiva T. Shahiri is XXX, Ingram School of Nursing, McGill University.

Madalina Boitor is XXX, Faculty of Dentistry, McGill University.

Gerald Chanques is XXX, Department of Anesthesia and Critical Care Medicine, University of Montpellier, France.

Kathleen A. Puntillo is XXX, PhyMedExp, University of Montpellier, INSERM, Centre National de la Recherche Scientifique.

The authors declare no conflicts of interest. 
challenge in the ICU. Many patients are unable to self-report their pain for reasons such as altered levels of consciousness, mechanical ventilation, heavy sedation, and delirium. ${ }^{3}\{\mathrm{AQ} 8\}$ Although the gold standard measure of pain remains the patient's selfreport, alternative behavioral assessment tools must be used for those unable to provide a reliable self-report of pain. ${ }^{46}$

This comprehensive review is an update of a previous review ${ }^{7}$ that evolved from the work completed on the 2013 clinical practice guidelines of the Society of Critical Care Medicine (SCCM). ${ }^{8}$ Psychometric analysis of available behavioral pain assessment tools was updated in the 2018 SCCM clinical practice guidelines ${ }^{4}$; new tools and validation studies published online ahead of print or published up to May 2019 were included in this review. Our aim for this comprehensive review was to analyze the development and psychometric properties (ie, reliability and validity) of behavioral pain-assessment tools for use in noncommunicative, critically ill adults.

\section{Methods}

\section{Search Strategy and Selection of Studies}

We updated the literature sources in the present review, using the same search terms and clinical databases described in our 2013 initial review ${ }^{7}$ and in the 2018 SCCM practice guidelines. ${ }^{4}$ Briefly, we used general Medical Subject Heading terms such as pain assessment, pain measurement, and the names of behavioral pain assessment tools. $\{A Q 9\}$ Searches were performed by an experienced research librarian using the following databases: Cumulative Index to Nursing and Allied Health Literature, Embase, Medline, PubMed, and Web of Science. We decided to exclude Scopus because it includes a variety of academic disciplines in addition to health sciences, and the results of a Scopus search were neither specific nor relevant to the aim of this review. Studies were eligible if the population included adults ages 18 years or older in the ICU and were in English, French, or any other languages spoken by the review coauthors or their graduate students. Abstracts, reviews, case reports, editorials, and letters to the editor were excluded. Titles and abstracts were screened by 2 reviewers. Disagreements about selection of studies were discussed, and consensus was reached. The majority of included papers were in English, but some were written in other languages (namely, French, Spanish, and Korean), and we had reviewers with proficiency in these languages.

\section{Psychometric Scoring Evaluation}

The psychometric scoring system was previously described ${ }^{7}$ and established with the consultation of 3 external experts in health measurement. The scoring system includes 5 main sections: (1) scale development (5 points), (2) reliability (5 points), (3) validity (10 points), (4) feasibility (2 points), and (5) clinical utility ( 1 point). The total score ranges from 0 to 23 . Reliability refers to the overall reproducibility of measures obtained from an assessment tool, and strategies evaluated as part of the psychometric system included internal consistency (ie, homogeneity of the items) and interrater reliability. We removed the item related to intrarater reliability because it is optional when poor interrater reliability findings are found, but we described it in the presentation of each tool in Results, when appropriate. Validity refers to the interpretation of assessment tool scores. Criterion validation (ie, comparison with the gold standard measure of pain: the patient's self-report) and discriminative validation (ie, comparison of pain scores between painful and nonpainful procedures) were evaluated. Each tool was attributed the highest score according to available study findings. However, when assumptions were not respected in the calculation of coefficient or statistical test in most studies, the score was reduced by 1 point on the specific item that was evaluated. Weighted scores were then calculated taking into account the importance of each section (ie, more weight for reliability and validity). A total weighted score was obtained by summing the weighted scores of each section and ranged from 0 to 20 . The interpretation of weighted scores was as follows: very good (score 15-20), good (score 12-14.9), acceptable but other studies are necessary (score 10-11.9), and unacceptable (score $<10)^{7}$

As described in our initial review, ${ }^{7}$ the quality of evidence for each tool was evaluated as high, moderate, low, or very low, having been adapted from the Grades of Recommendations, Assessment, Development, 
and Evaluation methodology used in the SCCM clinical practice guidelines process. ${ }^{8,9}$ High quality of evidence is established in a report when the scale development was well described, multiple validation strategies were tested and replicated in different studies in an overall large sample representative of the ICU population, and validation findings were consistent across most studies. Moderate quality of evidence is determined when some validation studies with an overall moderate sample size representative of some ICU patient groups were included, multiple validation strategies were used, and findings were consistent in most studies, but some important methodological limitations were identified. Low quality of evidence is determined when very few validation studies were included, with an overall small sample not representative of different ICU patient groups, and some steps of scale development and validation were missing. $\{\mathrm{AQ} 10\}$ When the psychometric properties related to the use of scale cannot be supported, a very low quality of evidence is established.

Data from studies included in the initial review of 2013 and in the 2018 SCCM clinical practice guidelines were extracted and psychometric scoring was done independently by 2 reviewers. In this updated review, data extraction and psychometric scoring of 3 new behavioral pain assessment tools were completed using a similar process. However, for new articles added in this review, data extraction was done by 1 reviewer and was checked by a second reviewer. Psychometric scoring of all tools was verified by 2 reviewers. Reviewers involved in the development of tools included in this review did not take part in data extraction of studies in which their behavioral pain assessment tool was tested.

Explanations of psychometric concepts and of the psychometric scoring system were provided to reviewers by the primary author (C.G.), who holds a doctorate in Nursing and Measurement. In addition to holding a doctorate degree, 2 of the reviewers (M. Bérubé, $\mathrm{M}$. Boitor) completed a graduate course in health measurement. Three reviewers (C.G., A.M.J., and K.A.P.) were involved in the 2013 initial review, 3 additional reviewers participated to the 2018 SCCM clinical practice guidelines (P.M.S., J.F.P., and G.C.), and the remaining 3 reviewers were not involved in the previous review.

\section{Results}

In the initial review, 72 studies were included for data extraction and analysis. The review was updated as part of the 2018 SCCM clinical practice guidelines, to which 20 other studies were added. ${ }^{4}$ In the present updated, comprehensive review, 3 new tools developed for other patient populations and tested for their use in critically ill adults (namely, the La Escala de Conductas Indicadoras de Dolor [ESCID] Behavioral Indicators for Pain Scale, Multidimensional Objective Pain Assessment Tool [MOPAT], and Nociception Coma Scale-Revised [NCS$\mathrm{R}])$ and 54 additional studies were included, for a total of 106 articles in which scale development, validation, feasibility, implementation into practice, and/or impact on patient outcomes were described. \{AQ11\} Items and interpretation of scoring of all behavioral pain assessments tools are described in Table 1, and a summary of all validation and implementation studies is given in Tables 2 and 3 (available online at www.aacnacconline.org). $\{$ AQ12 $\}$ Results are presented for 9 behavioral pain assessment tools developed for noncommunicative, critically ill adults and 4 such tools developed for other nonverbal populations but tested for their use in noncommunicative, critically ill adults.

Psychometric scoring for each tool is presented in Table 4. Four tools obtained very good weighted scores of greater than 15: the Behavioral Pain Scale (BPS), Behavioral Pain Scale-Nonintubated (BPS-NI), Critical-Care Pain Observation Tool (CPOT), and initial Nonverbal Pain Scale (NVPS-I) with moderate to high evidence. Good weighted scores (ie, scores of 12-14.9) were found for the revised NVPS (NVPS-R; moderate evidence), the MOPAT and the NCS-R-Intubated (NCSR-I) with low evidence. The Behavior Pain Assessment Tool (BPAT) obtained a high acceptable weighted score (10-11.9) with moderate evidence. Unacceptable weighted scores (ie, those $<10$ ) were obtained for all other tools with low or very low evidence.

\section{Behavioral Measures Developed for Noncommunicative, Critically III Adults}

Behavior Observation Tool. The psychometric score of the Behavior Observation Tool (BOT) was unchanged, because no new 
study was retrieved for this updated review. The BOT is a checklist of 38 behaviors clustered into facial responses, verbal responses, and body movements, ${ }^{10}$ which were inspired by items from previous pain observation tools (namely, the Children's Hospital of Eastern Ontario Pain Scale ${ }^{11}$ and the Pain Assessment Intervention Notation [PAIN] Scale $\left.{ }^{12}\right)$. Its content was evaluated by an expert committee for completeness and usability, and the tool was pretested with 10 critically ill adults. This tool was developed for the Thunder Project II and was tested in 5957 critically ill adults from 169 hospitals mainly located in the United States, with a few from Canada, United Kingdom, and Australia. ${ }^{10}$

Most patients were admitted to the ICU for a medical $(46.5 \%)$ or surgical $(38 \%)$ diagnosis and were able to self-report their pain. Discriminative validation was supported with increases in the frequency of almost all behaviors during standard care procedures. According to criterion validation, positive correlations were found between self-reported procedural pain intensity and the number of facial $(r=0.41)$, verbal $(r=0.49)$, and body movement responses $(r=0.37)$. Patients with procedural pain were $2.8,4.1$, and 10.3 times more likely to have increased facial responses, body movements, and verbal responses, respectively. These findings support the construct validity of the BOT in a large sample of patients in the ICU who could communicate.

A modified version of the BOT was tested during a nociceptive procedure (ie, endotracheal suctioning or turning) and gentle touch by $\mathrm{Li}$ et $\mathrm{al}^{13}$ in 48 adults who received mechanical ventilatory support and sedation during cardiac surgery. Some behaviors were observed only during the nociceptive procedure, such as grimacing $(17 \%)$ and random movement of extremities $(21 \%)$. Additional validation of the BOT is required in noncommunicative patients in the ICU, and reliability needs to be examined.

Behavior Pain Assessment Tool. The BPAT is a shorter version of 8 items of the BOT developed for the Thunder Project II. ${ }^{10}$ It has been published and was analyzed as part of the 2018 SCCM clinical practice guidelines. ${ }^{4}$ Initially available in English, the BPAT was translated into 11 different languages (Czech, Dutch, French, German, Greek, Spanish,
Italian, Polish, Portuguese, Danish, and Finnish) using a forward method. A teaching video was created for the research teams involved in the validation of the BPAT. The BPAT was validated in 3851 patients from 192 ICU settings in 28 countries. ${ }^{14}$ Interrater reliability was supported by good to excellent $(>0.60) \kappa$ coefficients for most behavioral items, which were assessed at rest and during procedures by 2 raters from the ICU care team (eg, nurses, physicians, respiratory therapists, physiotherapists). A few moderate $\kappa$ coefficients were found for muscle rigidity $(0.43)$, wince $(0.50)$, and clenched fists $(0.51)$ at rest. Discriminative validation was demonstrated, with behaviors more likely to be present during procedures than at rest in patients in the ICU who were able or not able to self-report. Regarding criterion validation, moderate correlations were found during procedures between the BPAT scores and the 0 to 10 pain intensity $(r=0.54)$ and pain distress $(r=0.49)$ scores. A BPAT cut-point score greater than 3 could adequately classify $75 \%$ of patients with or without severe pain with good sensitivity $(62 \%)$ and specificity (75\%). An additional item related to compliance with mechanical ventilatory support would enhance its applicability in patients in the ICU who were receiving such support. The BPAT's feasibility and implementation in clinical practice need to be studied.

Behavioral Pain Scale and Behavioral Pain Scale-Nonintubated. A total of 39 published ICU studies using the BPS and/or BPS-NI were selected, including 19 new articles published since the 2018 updated SCCM practice guidelines. ${ }^{4}$ The psychometric scores of both the BPS and the BPS-NI were increased by more than 2 points with cumulative evidence. A training poster for the BPS/BPS-NI ${ }^{15}$ is available on the SCCM's ICU Liberation webpage (https://www.sccm.org/ICULiberation/Resources/Behavioral-Pain-ScaleTraining-Poster). Studies were conducted in 17 countries. The original versions of the BPS $^{16}$ and BPS-NI ${ }^{15}$ were developed in French, and both tools were translated into English using a forward method. The BPS was translated in 9 other languages: Brazilian, ${ }^{17}$ Brazilian Portuguese, ${ }^{18}$ Dutch, ${ }^{19}$ Italian, ${ }^{20}$ Chinese, ${ }^{21}$ Mandarin, ${ }^{22}$ Norwegian, ${ }^{23}$ Polish, ${ }^{24}$ and Swedish. ${ }^{25}$ The BPS-NI was translated in 4 other languages: Chinese, ${ }^{26}$ Italian, ${ }^{20}$ Norwegian, ${ }^{23}$ and Swedish. ${ }^{25}$ All used a forward-backward 
translation method except for the Dutch version of the BPS, ${ }^{19}$ for which a forward method was used. The Swedish versions of the BPS and BPS-NI ${ }^{25}$ were translated following the 10-step process established by the International Society for Pharmacoeconomics and Outcomes. ${ }^{26}$ \{AQ13\} The Chinese versions of the BPS and BPS-NI ${ }^{21,27}$ and the Polish version of the BPS $^{24}$ were translated using a rigorous, multiple-step process with forward-backward translation, expert committee, and pretest.

The BPS was validated in 25 studies involving 1791 patients in the ICU who had various medical, surgical, and/or trauma diagnoses, ${ }^{16,19,21,22,24,28-39}$ and in studies that included specific ICU groups such as patients with brain injury ${ }^{17,40-45}$ and patients who underwent cardiac surgery. ${ }^{46}\{\mathrm{AQ} 14\}$ The BPS-NI was validated in 2 studies ${ }^{15,20}$ with 75 patients in medical and surgical ICUs, including 30 with delirium. ${ }^{15}$ Both tools were simultaneously validated in 6 studies with 658 patients in medical and surgical ICUs. ${ }^{18,23,25,27,46,47}$ \{AQ15\}

Internal consistency was examined in 14 studies for the BPS, ${ }^{17,19,22,24,29-31,35,38-41,45,48} 2$ studies for the BPS-NI, ${ }^{15,20}$ and 3 studies for both tools. ${ }^{26,46,47}$ Good ( $\left.>0.70\right)$ or acceptable (0.50$0.70)$ Cronbach $\alpha$ values were found in most studies, and a low value $(<0.20)$ was only found in patients at rest preprocedure for the Polish version of the BPS. ${ }^{24}$ However, in 9 studies $(69 \%),{ }^{15,22,29-31,35,40,46,47}$ Cronbach as were calculated using dependent data (ie, repeated observations within subjects), which may inflate the coefficient values.

Interrater reliability was tested in 18 studies for the BPS, ${ }^{16,17,19,21,24,28-31,33,35,36,38-40,44,45,48}$ both studies for the BPS-NI, ${ }^{15,20}$ and all 6 studies for both tools. ${ }^{18,23,25,27,46,47}$ Weighted $\kappa$ and/or intraclass correlation coefficients (ICCs) greater than 0.60 were reported in most studies, and a lower value $(0.36)$ was obtained at rest for the Norwegian version of the BPS-NI. ${ }^{23}$ Low percentages of agreement $(36 \%-46 \%)$ were also reported during postprocedure assessments for the BPS. ${ }^{38}$ Such findings may be obtained when raters do not focus on the same behaviors during the observation period. Not enough practice with the tool may also explain lower results. Nurses, physicians, and other health professionals were involved as raters in most studies except that of Liu et al, ${ }^{47}$ in which raters were the investigator and a research assistant.
Regarding validation strategies, discriminative validation comparing painful and nonpainful conditions or standard care procedures (Table 2) was examined in most validation studies $(n=29$ of $32 ; 91 \%)$. Significant increases in BPS/BPS-NI scores during painful procedures were found in 2 studies for the BPS-NI ${ }^{15,20}$ and all 6 studies that used both tools, ${ }^{18,23,25,27,46,47}$ compared with rest and/ or nonpainful procedures. . $^{15-21,23-25,27,29-31,33-38,40-48}$ \{AQ16\} The 2 most common painful procedures were endotracheal/tracheal suctioning ( $\mathrm{n}=18$ studies) and turning or repositioning/ changing position ( $\mathrm{n}=16$ studies). Klein et $\mathrm{al}^{18}$ performed a standardized stimulation by pressure algometry for the validation of the Brazilian Portuguese version of the BPS and BPS-NI. Nonpainful procedures were performed in 17 studies, and the 3 most commonly used were eye cleaning $(n=5$ studies),,$^{17,38,41,44,45}$ noninvasive blood pressure ( $n=3$ studies), ${ }^{24,33,47}$ and arterial or central catheter dressing change ( $\mathbf{n}=3$ studies). ${ }^{15,16,29}$

Criterion validation was tested in 7 studies for the BPS, ${ }^{21,29,32,33,36,37,40}$ in 1 study for the BPS-NI, ${ }^{20}$ and in 1 study for both tools. ${ }^{27}$ Moderate to high correlations (range, 0.560.89 ) were obtained between BPS/BPS-NI and numeric rating scores (NRS) ranging from 0 to 10 or descriptive scores ranging from 0 to 4. ${ }^{20,27,29,36,37}$ Lower correlations $(<0.40)$ were found between BPS and NRS ranging from 0 to 10 when patients were at rest. ${ }^{32,36} \mathrm{~A}$ cutpoint score was only explored for the English, French, and Chinese versions of the BPS. Receiver-operating curve (ROC) analysis showed that the BPS cut-point ranged from 5 to 6.5 , with better classification during painful procedures such as nursing care and endotracheal suctioning (area under the curve [AUC] range, 0.73-0.83) $)^{21,33,37}$ compared with the other tools (AUC range, 0.60-0.73). . $^{32,37}$ \{AQ17\} Sensitivity varied from $52 \%$ to $90 \%$ and specificity from $46 \%$ to $92 \%$. Selfreports of pain at rest and during procedures were combined in some studies for the calculation of correlation ${ }^{37}$ or ROC analysis. ${ }^{33}$ In the Bernard et al study, ${ }^{40}$ BPS scores during painful procedures (eg, turning, endotracheal suctioning) were used as the reference standard compared to preprocedure BPS scores in 50 patients in the ICU who had brain injury. Correlated ROC curves were compared and the authors reported an AUC of 0.96 for a BPS cut-point score of 4 . The threshold was 
lower in this sample of patients with brain injury in the ICU than the thresholds obtained when the patient's self-report of pain was used as the gold standard for this type of analysis. \{AQ18\} To our knowledge, cut-point scores of other language versions of the BPS and BPS-NI remain to be studied.

The feasibility and clinical relevance of the use of the BPS were evaluated in 4 studies. ${ }^{16,40,46,49}$ The BPS was evaluated as easy to use or to learn, precise or accurate, and useful by the majority of clinicians (most were nurses). In the initial validation study of the BPS, few evaluators $(25 \%)$ expressed some concerns regarding its complexity. ${ }^{16}$ Five implementation studies with results reported in 6 papers in 4 countries (Australia, France, Germany, and Norway) were identified: 3 for the BPS only (French and English versions) ${ }^{49-51}$ and 3 for the BPS and BPS-NI (French and Norwegian versions). ${ }^{52-54}$ Nurses' adherence to use of the Norwegian version of the BPS/ BPS-NI as part of a pain management algorithm was high $(75 \%) .^{53} \mathrm{An}$ increase in the documentation of pain assessments ${ }^{50,54}$ and decrease in the incidence of severe pain and adverse events ${ }^{49,52}$ were described. A reduction in mechanical ventilation duration and/or ICU length of stay was found in 2 studies, ${ }^{49,54}$ but no change was reported in 1 study. ${ }^{51}$ Implementation of pain and delirium monitoring was associated with a decrease in mortality rate in 1 study. ${ }^{50}\{\mathrm{AQ} 19\}$ Changes in the ordering and/or use of analgesics and sedatives were also described.

Critical-Care Pain Observation Tool. A total of 59 CPOT studies conducted in the ICU setting were included in this review, 35 of which were new articles published after the previous review. $\{\mathrm{AQ} 20\}$ The CPOT reached the maximum psychometric score based on cumulative and new evidence. Studies were conducted in 19 countries. The CPOT was initially developed in French ${ }^{55,56}$ (using various sources, including literature, chart reviews, and consultation with critical care clinicians) and a content validation process, ${ }^{56}$ and it was translated into English using a forward-backward method..$^{58}$ The directions for CPOT use are available in French $^{59}$ and English $^{60}$ and can be found on the SCCM's ICU Liberation webpage (http:// www.sccm.org/ICULiberation/Resources/ Critical-Care-Pain-Observation-Tool-How-toUse-it). It is now available in 17 other languages (Table 2). Most used a forwardbackward translation method (ie, the Danish ${ }^{61}$ Dutch, ${ }^{62}$ German ${ }^{63}$ Greek, ${ }^{64}$ Japanese, ${ }^{65}$ Korean, ${ }^{66}$ Persian ${ }^{67}$ Polish, ${ }^{68}$ Mandarin,${ }^{22}$ Swedish, ${ }^{69}$ and Turkish ${ }^{70}$ versions of the CPOT). The Spanish version ${ }^{71}$ and another Dutch $^{19}$ version of the CPOT were translated using a forward method. The translation method of the Italian version of the CPOT was not specified by the authors. ${ }^{72}$ The Finnish and the Norwegian versions of the $\mathrm{CPOT}^{73,74}$ were translated following the International Society for Pharmacoeconomics and Outcomes 10-step process. ${ }^{26}$ The Brazilian Portuguese $^{18}$ and Chinese ${ }^{75}$ versions were translated using a similar rigorous process with forward-backward translation, cognitive interviewing, expert committee, and pretest. The language version of the CPOT was not specified in 9 studies conducted in countries where English is not the primary language.

In addition to its content validation, ${ }^{57}$ the CPOT was validated in 47 studies selected for this review, with a total of 3966 patients in the ICU who had various diagnoses and were or were not able to self-report pain. Most studies included patients with medical and/or surgical diagnoses $(\mathrm{n}=31$ studies) ${ }^{18,19,22,31-34,37,46,47,58,59,61-63,66-69,71,74-84}$; some of these studies also included trauma patients $(\mathrm{n}=7$ studies) $)^{58,59,66,67,78-80}$; others specifically included patients who had undergone cardiac surgery $(\mathrm{n}=9 \text { studies; } \mathrm{n}=730 \text { patients; } 19 \%)^{48,56,70,85-90}$ or who had brain injury ( $n=7$ studies; $n=690$ patients; $18 \%)^{42,91-96}$

Internal consistency was examined in 17 studies. . $^{19,22,31,46-48,61-63,67,69,70,75,77,81,83,95}$ Good (>0.70) and acceptable (0.50-0.70) Cronbach $\alpha$ values were found in most studies, and a very low value $(0.31)$ was only found at rest after a procedure, with the Swedish version of the CPOT ${ }^{69}$ However, in 7 studies, ${ }^{22,31,47,62,77,81,83}$ Cronbach $\alpha$ values were calculated using dependent data (ie, repeated observations).

Interrater reliability was reported mainly with weighted $\mathrm{\kappa}$ and/or ICC values in 33 studies, $18,19,31,33,46-48,56,58,61-63,66-71,74-78,81,84,85,88,90-92,94-96$ and values greater than 0.60 were obtained in 30 of these studies. Clinical staff (mainly nurses) were involved as raters in 22 studies, whereas in other studies, only the investigators and/or research staff were raters. Low values $(<0.40)$ were reported mainly at rest. ${ }^{85,88}$ Lower ICCs were found both at rest $(0.38)$ and during turning (0.56) among 4 
nurses who used the Dutch version of the CPOT. ${ }^{62}$ These nurses received a 90 -minute standardized training, but there was no information regarding the evaluation of their competence using the Dutch version of the CPOT before data collection. When interrater reliability is not satisfactory, intrarater reliability is a useful strategy to identify low raters. ${ }^{97,98}$ However, it is only possible to do with videos so raters can view them at a later date (a minimum 1-month interval is recommended) and perform their scoring of the same patient and under the same conditions. Intrarater reliability was examined in 2 studies $^{85,91}$ and ICC values greater than 0.80 were obtained for each rater except for 1 value of 0.54 for assessment at rest by 1 rater. $^{85}$

Discriminative validation was examined in most of validation studies $(n=42$ of 47 ; $89 \%$ ). Significant increases in CPOT scores during painful procedures were found in all these studies compared with rest and nonpainful proce-

dures. ${ }^{18,19,31,33,34,37,42,46-48,56,58,59,61-63,66-71,74-82,84,85,88-96}$ The

2 most common painful procedures were turning or repositioning/changing position ( $\mathrm{n}=33$ studies), and endotracheal/tracheal suctioning ( $\mathrm{n}=16$ studies). Interestingly, oral care procedures (eg, oral suctioning, tooth brushing, swabbing with a sponge toothette) were considered as painful in a study by Dale et $\mathrm{al}^{78}$ but as nonpainful in the studies led by Rijkenberg et $\mathrm{al}^{19,48}$ (no specific description of the procedure was provided). In addition, a standardized stimulation by pressure algometry was performed for validation of the Brazilian Portuguese version of the CPOT. ${ }^{18}$

Nonpainful procedures were performed in 20 studies; the 2 most commonly used were noninvasive blood pressure using cuff inflation $(\mathrm{n}=9 \text { studies })^{33,47,58,59,75,81,85,91,96}$ and soft touch ( $\mathrm{n}=4$ studies). ${ }^{63,84,92,94}$

Criterion validation was examined in 24 studies using the patient's self-report of pain presence and/or pain intensity (ie, 0-10 NRS, visual analog scale, or descriptive scale). The CPOT consistently has been associated with self-report of the presence of pain (yes/no). Moderate to high correlations were found with the self-report of pain intensity with higher coefficients (range, 0.42-0.84) during painful procedures. . $^{37,56,58,61,76,77,85,92,96}$ Lower correlations $(<0.40)$ were found while patients were at rest in a study combining delirious and nondelirious patients, ${ }^{32}$ in patients with spinal cord or brain injury, ${ }^{95}$ and in some cardiac surgery samples. ${ }^{87,88}$ The best CPOT cutpoint score that adequately classifies self-reported pain during procedures (AUC range, $72 \%-91 \%$ ) varied between $2^{37,63,68,75,78,92,99}$ and $3 .^{33,58,61}$ During procedures, sensitivity ranged from $67 \%$ to $93 \%$ and specificity from $46 \%$ to $90 \%$. The CPOT cutpoint score was lower at rest and ranged between $1^{57}$ and $2,32,66,75$ with sensitivity ranging from $47 \%$ to $81 \%$ and specificity from $65 \%$ to $97 \%$. Self-reports of pain at rest and during procedures were combined in some studies to establish the best CPOT cut-point score. ${ }^{62,94,95}$

The feasibility and implementation of CPOT in ICU settings were described in 11 papers. The English, French, and Italian versions of the CPOT were implemented in 5 countries (Australia, Canada, Iran, Italy, United Kingdom, and United States) mainly in mixed ICUs (ie, medical/surgical/trauma). The CPOT was rated as feasible and clinically relevant by ICU nurses..$^{59,60,96,100,101}$ Training in the use of the CPOT allowed nurses to improve their diagnosis of pain in patients with low levels of consciousness. ${ }^{102}$ However, ICU nurses highlighted that the training did not improve communication of pain assessment findings with physicians who were not familiar with the tool. ${ }^{101}\{\mathrm{AQ} 21\}$ Documentation of pain assessments significantly increased after implementation of the CPOT, reaching or exceeding the minimum frequency interval (ie, every 2-3 hours). ${ }^{103-107}$ Implementation of CPOT and standardized protocols also led to a reduction in sedative use $^{103,104,107,108}$ and led to appropriate use of opioids based on regular assessments to evaluate effectiveness of analgesia. ${ }^{103-106,109}\{$ AQ22\} Positive impacts on patient outcomes also were reported, such as fewer complications, ${ }^{109}$ shorter time requiring mechanical ventilatory support, ${ }^{108}$ and a low recollection of severe pain by patients surviving their stay in the ICU. ${ }^{103}$

Behavioral Indicators of Pain Scale. To our knowledge, the ESCID was analyzed for the first time in the present review. It was developed in Spanish by Latorre-Marco et $\mathrm{al}^{110}$ and is an adaptation of the Campbell's scale, ${ }^{111}$ which was suggested by the Analgesia and Sedation Work Group of the Spanish Society of Intensive Care Medicine and Coronary Units. ${ }^{112}\{A Q 23\}$ As part of the adaptation 
process, the authors performed content validation with 13 expert clinicians ( 9 nurses and 4 physicians), and a content validity index was calculated for each item. The lowest content validity index was determined for the item "compliance with ventilator" and it was modified to improve its clarity and meaning. The scale is also available in English ${ }^{113}$ but the translation method was not specified and the English version does not appear to have been validated yet.

The ESCID was validated with a total of 356 patients in the ICU setting in Spain: 232 with mixed diagnoses ${ }^{110,113}$ and 124 patients with trauma. ${ }^{114}$ Regarding internal consistency, Cronbach $\alpha$ values from 0.69 to 0.85 were obtained for the ESICD total score or when calculated with 1 item deleted, but repeated observations were used in the calculation of these coefficients. ${ }^{110,113}$ A Cronbach $\alpha$ of 0.63 was also reported in patients who had a Richmond Agitation-Sedation Score (RASS) of $-5,{ }^{113}$ which appears irrelevant because behaviors are not observable in unresponsive patients. Interrater reliability was examined with raters from the research team and trained nurses in 2 studies ${ }^{113,114}$ and by members of the research team only in the initial validation study. ${ }^{110}$ The $\mathrm{K}$ coefficients using an ESCID cut-point score of greater than 3 ranged from 0.66 to 1 at all assessment times (ie, before, during, and after procedures) and at the 3 data collection days in the Lopez-Lopez et al study. ${ }^{114}$ Analyses of variation were not significant when comparing the ESCID mean scores of raters in the Latorre-Marco et al studies. ${ }^{110,113}$ The authors mentioned checking for intrarater reliability by comparing ESCID scores between procedures for each rater. However, such a procedure is not appropriate, because raters should have observed the patient during the same procedure twice. Considering that acute pain can vary over time, intrarater reliability through the use of videos appears the most appropriate method to allow raters to score the patient again under the same condition but at a later time.

Discriminative validation was examined in all 3 studies. Consistent findings were obtained with higher scores (ie, increases by $>2$ points) during painful procedures (eg, turning/repositioning, mobilization, tracheal suctioning) when compared with preprocedure rest and a nonpainful procedure (ie, gentle rub of a gauze cloth on intact skin). ${ }^{110,113,114}$ Criterion validation remains to be tested and is a useful strategy to establish a cut-point score for clinical use. Feasibility and implementation of the ESCID in clinical practice also need to be studied.

Nonverbal Pain Assessment Tool. The Nonverbal Pain Assessment Tool (NPAT) is available in English and was validated in 220 medical and surgical patients from 4 adult ICUs. ${ }^{115}$ No new article was retrieved for this tool when compiling the present review, and the NPAT was described in our previous review.' Briefly, internal consistency ( $\alpha=$ 0.82 ) was high, and interrater reliability was moderate to high $(r=0.52-0.88)$ between 2 nurses' rating scores ( 5 teams of 2 nurses participated). Low correlation coefficients (ie, 0.21-0.31) were found between NPAT scores and patients' self-reports of pain intensity on a scale of 0 to 10 . No information about the conditions of pain assessments (eg, at rest, during care procedures) was provided. These findings supported the reliability but not the validity of the NPAT use, and additional validation of the tool would be necessary.

Nonverbal Pain Scale_Initial and Revised Versions. Of the 12 studies using NVPS-I or NVPS-R included in the present review, 5 were published after the previous review. \{AQ24\} Ten were validation studies with a total of 778 patients in the ICU, and 2 were implementation studies. The psychometric scores of both versions of the NVPS were increased by more than 3 points with new evidence. Two versions of the NVPS exist: the NVPS-I and the NVPS-R. The initial version of the NVPS was developed in English and includes 3 behavioral and 2 physiological indicators; its content was evaluated by critical care experts. ${ }^{116}$ The NVPS-R, in which the skin physiologic indicator was modified for a respiratory item (ie, respiratory rate, oxygen saturation, compliance with ventilator), is also available. ${ }^{117}$ In addition to the English version, the NVPS-I was translated into Polish using a forward method and a content validation process with ICU nurses,${ }^{24}$ and the NVPS-R was translated into Turkish using a forward-backward method and a content validation process with 9 specialists ${ }^{118}$; an overall content validity index of 1.00 was reported for the Turkish version. $\{\mathrm{AQ} 25\}$ Both versions of the tool were translated for a study conducted in Iran, but neither the language nor 
the translation method was specified by the authors. ${ }^{119}$

The NVPS-I was validated in 3 studies with 237 patients with medical, surgical, trauma, neurologic, or burn diagnoses. ${ }^{24,36,116}$ The NVPS-R was validated in 5 studies with 417 patients with medical, surgical, trauma, and neurologic diagnoses. ${ }^{31,35,46,96,118}$ Both versions of the tool were simultaneously validated in 2 studies with 124 patients with various diagnoses. ${ }^{117,119}$

Internal consistency was examined in 8 studies and results were variable for both the NVPS-I and the NVPS-R: Cronbach $\alpha$ coefficients ranged from 0.36 to 0.72 at different times. ${ }^{24,117}$ The highest values of 0.62 and 0.78 were obtained during the painful procedure for the NVPS- $\mathrm{I}^{117}$ and the Turkish version of the NVPS-R, ${ }^{118}$ respectively. The value of Cronbach $\alpha$ was improved during the nonpainful and painful procedures when physiologic indicators (eg, vital signs, skin) were removed in the Polish version of the NVPS-I. ${ }^{24}$ Higher Cronbach $\alpha$ values (0.75$0.86)$ were obtained when repeated observations were used for the calculation of the coefficients. . $^{31,35,46,116,119}$

Interrater reliability was tested with raters from the research team and ICU nurses in most studies but not in that of Rahu et al, ${ }^{36}$ in which only the investigators were involved as raters. Percentages of agreement $(>90 \%)^{117}$ as well as ICC values and $\kappa$ coefficients were high (0.60-0.95) in several studies. ${ }^{31,35,47,119}$

Lower interrater reliability coefficients were found with the Polish version of the NVPS-I $(\kappa=0.44)^{24}$ and for the English version of the NVPS-R, with ICCs in the latter ranging from 0.34 to 0.49 at rest before and after procedures and an ICC of 0.55 during the nonpainful procedure (ie, noninvasive blood pressure). ${ }^{96}\{\mathrm{AQ} 26\}$

Discriminative validation was tested in most studies ( $\mathrm{n}=7$ of $10 ; 70 \%$ ) and was supported by significant increases in the tool's scores during painful procedures compared with rest and nonpainful procedures. ${ }^{24,35,36,46,96,117,119}$ The most common painful procedures were endotracheal suctioning and/ or turning or repositioning, ${ }^{24,35,36,46,96,117,119}$ and various nonpainful procedures were used across studies. It is worth mentioning that the skin indicator of the NVPS-I did not increase significantly during endotracheal suctioning. ${ }^{117}$
Criterion validation was explored in only one study of the NVPS- $\mathrm{I}^{36}$ and one of the NVPS-R ${ }^{96}$; in the Iranian study, both versions were used. ${ }^{119}$ In association with the 0 to 10 scale of self-reported pain intensity, a low correlation of 0.31 was found during turning for the English version of the NVPS-R, ${ }^{96}$ and moderate correlations 0.41 and 0.56 were obtained during physical examination and during endotracheal suctioning for the English version of the NVPS-I, respectively. ${ }^{36}$ Using 269 self-reports of the presence or absence of pain from 60 patients in the ICU, the authors of the Iranian study reported sensitivity and specificity greater than $95 \%$, with a cut-point score of 1.5 for both the translated versions of the NVPS-I and of the NVPS-R. ${ }^{119}$

The implementation of the English version of the NVPS-I in 2 neurological and trauma ICU settings was evaluated in Canada ${ }^{120}$ and in the United States. ${ }^{121}$ In the latter study, by Sacco et al, ${ }^{121}$ the NVPS-I was implemented as part of an analgesia and sedation guideline. There was an increase in the documentation of pain assessments, and patients reported an overall decrease in their pain after implementation of the tool. ${ }^{120}$ A decrease in the average number of sedation days and in analgesic treatment duration was found in that implementation study. ${ }^{121}$ The tool or guideline was rated as easy to use by ICU nurses in both studies. Although the ICU nurses' satisfaction with the guideline was positive in the Sacco et al study, ${ }^{121}$ nurses in the Topolovec-Vranic et al study ${ }^{120}$ were less likely to agree that the NVPS-I would ease the assessment of their patients' pain, make them confident to request fewer or more analgesics, or improve their pain management practice. The feasibility and clinical relevance of the English version of the NVPS-R was evaluated by 10 ICU nurses in 1 validation study in Canada. ${ }^{96}$ Although the NVPS-R was rated as easy to use by nurses, its clinical relevance was only supported by $20 \%$ of them. Physicians' practices with regard to pain management and inconsistent pain assessment and management practices of the staff were mentioned as major barriers by ICU nurses. $^{96}$

Pain Assessment Intervention Notation. The PAIN was analyzed in our previous review, ${ }^{7}$ and no new article was retrieved for the present update. The PAIN algorithm is a 
tool developed by a team of critical care nurses and pain experts and intended to combine pain assessments with subsequent pain interventions. ${ }^{12}$ Clinicians are directed to first use a checklist of 4 behaviors and 5 physiologic signs to determine the presence or absence of pain. The nurse is then prompted to elicit the patient's degree of pain intensity on a 0 to 10 NRS. The management steps of the algorithm involve assessing for potential problems influencing opioid administration and making an analgesic treatment decision. The PAIN tool was tested with 31 recently extubated, self-reporting adults in the ICU after surgery. ${ }^{12}$ The number of behavioral and physiological indicators observed was significantly associated with the nurses' proxy ratings of 0 to 10 pain intensity on an NRS $(r=$ 0.17 to 0.77$)$. However, the relationship between the patient's self-report of pain intensity and behavioral and physiological indicators was not calculated; therefore, criterion validation was not described in this sample. Nine of 11 nurse evaluators of 31

patients deemed the instrument to be helpful, whereas a few nurses $(n=4)$ found the PAIN tool to be too complex. ${ }^{122}$ Although the PAIN tool was tested in a small sample of patients in the ICU who were able to communicate, most psychometric properties were not examined. The PAIN tool is based on the nurse's clinical judgment and appears to be more of a pain-management educational tool than a single pain scale per se.

\section{Tools Developed for Non-ICU Populations}

Face, Legs, Activity, Cry, Consolability. The psychometric analysis of the Face, Legs, Activity, Cry, Consolability (FLACC) was described in our previous review, ${ }^{7}$ and no new article was retrieved for the present update. The tool was initially developed for children with cognitive impairment, ${ }^{123}$ and its use was validated in a sample of 29 adults and 8 pediatric patients from medical and surgical ICUs by Voepel-Lewis et al. ${ }^{124} \mathrm{~A}$ Cronbach $\alpha$ coefficient of 0.88 was obtained using dependent data $(\mathrm{n}=73$ observations from 37 patients), which was improved to 0.93 by removing the "cry" item from the scale. Such a finding may indicate that the cry item is not relevant to adults in the ICU. Interrater reliability was demonstrated with an ICC of 0.98 for the FLACC scores between 2 nurse raters who completed 60 observations in 29 adult patients in the ICU. Significant reductions in FLACC scores $(P<.001)$ comparing before and after analgesic administration or painful and nonpainful procedures supported discriminative validation. Additional research is necessary to adapt the content of the FLACC for the ICU adult population and to establish the reliability and validity of its use in noncommunicative, critically ill adults.

Multidimensional Objective Pain Assessment Tool. The Multidimensional Objective Pain Assessment Tool (MOPAT) was newly analyzed in this review. The tool includes 4 behavioral and 4 physiologic indicators. Its content development was based on the ratings of pain descriptors by 20 nurses according to their own experience of assessing pain in noncommunicative and cognitively impaired patients in hospice. ${ }^{125}$ The validity, reliability, and clinical usefulness of the MOPAT was tested in noncommunicative hospice patients. ${ }^{125}$ The blood pressure indicator was reported as having a negligible effect. ${ }^{125}$

The MOPAT (including the blood pressure indicator) was evaluated in 27 patients in the medical ICU who were unable to self-report pain. ${ }^{126}$ Internal consistency of MOPAT total scores was moderate during and after painful procedures, with Cronbach $\alpha$ values of 0.68 and 0.72 , respectively. Cronbach $\alpha$ values were higher for the behavioral component $(\geq 0.80)$ compared with the physiologic component during and after the painful procedures (0.37 and 0.57 , respectively). \{AQ27\} Interrater agreement among 3 raters (from 2 investigators and 21 nurses) was $68 \%$ and $83 \%$ for the behavioral component, $80 \%$ and $79 \%$ for the physiologic component ( $\kappa$ coefficients not provided) at the 2 times. Discriminative validation was demonstrated for behavioral and physiologic indicators, as well as for the MOPAT total score-all showing significantly higher scores during versus after a painful procedure (eg, turning, suctioning). The physiologic indicators had a very small effect on the variation of the total score. The Clinical Utility Questionnaire was used to evaluate the nurses' perceptions regarding the usefulness of the MOPAT. The tool was considered easy to use and helpful in determining the presence of pain in a noncommunicative patient by more than $93 \%$ of the responders, 
but $20 \%$ were undecided about whether the tool assisted them in communicating to others about a patient's pain. ${ }^{126}$

The MOPAT was validated in a small ICU sample but was evaluated as feasible and clinically useful by ICU nurses. ${ }^{126}\{\mathrm{AQ} 28\}$ Overall, the behavioral indicators appear to be the most helpful, whereas the physiologic indicators require additional study. The item related to "patient sounds" is not applicable to patients receiving mechanical ventilatory support and would require an alternative item for this ICU clientele. Implementation studies in clinical practice are needed.

Nociception Coma Scale-Revised. The NCS- $\mathrm{R}^{127}$ is a short version (with the visual response removed) of the 4-item NCS developed for nociception and pain assessment in patients with brain injury with disorders of consciousness. ${ }^{128}$ The initial version of the NCS was developed on the basis of an extensive literature review and pilot data, and it was tested in 48 patients from various settings (eg, acute care, neurology, neurorehabilitation, nursing homes) but not in the ICU.

The NCS-R was newly analyzed in the present review. It was tested in a total of 60 acute care patients with brain injury in 2 studies by Chatelle et al. ${ }^{127,129}$ In their 2012 study, ${ }^{127} 21$ patients with acute brain injury (including patients in the ICU) were part of a larger sample with chronic patients who were 1 month to 6 years after injury $(n=64)$. Patients were assessed at baseline (rest), with a nonnociceptive stimulation (taps on the patient's shoulders), and with a nociceptive stimulation (pressure on the nail bed measured in Newton-meters). In this study, ${ }^{127}$ Chatelle et al initially used the NCS, with which they obtained poor validity results. They decided to remove the visual response item, which led to improved findings. The NCS-R could discriminate among baseline, the nonnociceptive, and the nociceptive stimulations. The researchers used ROC analysis to compare curves between the non-nociceptive and the nociceptive stimulations. ${ }^{127} \mathrm{~A}$ cut-point score of 4 with a sensitivity of $73 \%$ and a specificity of $97 \%$ was found. The NCS-R cut-point score varied according to the patient's level of consciousness and was lower (score of 3) for those in a vegetative state. In the 2016 study of Chatelle et al, ${ }^{129}$ discriminative validation of the NCS-R was supported with significant lower scores after administration of an analgesic compared with before administration in 39 patients with brain injury who were in the ICU and neurology units. Chatelle et al used an NCS-R cutpoint score of 4 as a criterion to confirm the presence of pain before the administration of an analgesic. Neither internal consistency nor interrater reliability were examined in these studies. ${ }^{127,129}$ Of note, the score of 3 for the facial expression item (the cry item) is greater than that given for grimace (score of 2). It remains unclear from the scoring description if facial contraction should be present in addition to cry to obtain the highest score on this item. ${ }^{128}$ Also, the item "verbal response" would not be applicable to patients receiving mechanical ventilatory support.

To make the NCS-R applicable to patients in the ICU receiving mechanical ventilatory support, Bernard et $\mathrm{a}^{10}$ replaced the verbal response item of the NCS-R with the compliance with ventilator item of the BPS and called it the NCS-R-I (I for intubated). They tested this version in 50 patients in the ICU with brain injury who were intubated. A Cronbach $\alpha$ of 0.69 was found for internal consistency, and interrater reliability was supported with a weighted $\kappa$ of 0.84 between the investigator and nurse raters. Significant increases in the NCS-R-I scores were found during both the non-nociceptive (ie, assessment of the sedation level using the RASS procedure) and the nociceptive procedures (ie, tracheal suctioning and turning), but the increase was greater during the nociceptive procedures. Using the nociceptive procedures as the reference criterion and the nonnociceptive procedure as a comparator, correlated ROC curves resulted in an AUC of 0.97 for an NCS-R-I cut-point score of 2. ICU nurses ( $\mathrm{n}=15$ of $21 ; 71 \%$ response rate) evaluated the NCS-R-I as precise $(93 \%)$, useful $(100 \%)$, and easy to learn $(80 \%)$.

Pain Assessment in Advanced Dementia Tool. The Pain Assessment in Advanced Dementia (PAINAD) tool was developed to assess pain in individuals with advanced dementia. ${ }^{130}$ It was validated by PaulsonConger et $\mathrm{a}^{183}$ for use in 100 adult patients in 4 medical ICUs (cardiac, medical, surgical, and neurologic) of a level I trauma center in the United States. The PAINAD tool was analyzed as part of the 2018 SCCM clinical practice guidelines, ${ }^{4}$ and 1 new validation study with 50 patients who were admitted to 
the ICU for spinal cord or brain injury was added in this review, ${ }^{95}$ which led to a 3-point increase in its psychometric score. In the study by Paulson-Conger et $\mathrm{al},{ }^{83}$ patients were assessed only once, while at rest, by the principal investigator or trained data collectors (1 per critical care unit). Internal consistency was supported with a Cronbach $\alpha$ of 0.80 . Correlation between PAINAD and CPOT scores was 0.86 . Such a high correlation between the tools' scores is not surprisingthey include similar items. Comparing 2 tools measuring the same construct (in this case, pain behaviors) refers to convergent validation but, ideally, it should be done by selecting 2 different assessment methods and not similar tools. ${ }^{98}$ In the study by Sulla et al, ${ }^{95}$ a correlation of 0.67 was found between the PAINAD and self-reported NRS scores and almost a perfect classification ability $(\mathrm{AUC}=$ 0.98 ) using repeated observations. The use of the PAINAD tool in critically ill adults cannot be supported, because some validation strategies remain to be examined (ie, interrater reliability) or replicated (ie, criterion and discriminative validation), and some tests (correlation and ROC curve analysis) were performed using methods not considering dependent data. In addition, the PAINAD tool's content should be adapted for use with patients receiving mechanical ventilatory support, for whom the item "vocalization" is not applicable.

\section{Discussion}

Validation studies of behavioral pain assessment tools in critically ill adults have increased substantially in recent years. In fact, half of all studies included in this review were published in the last 3 years. Considering these additional studies, higher psychometric scores were obtained for many tools, including the BPS, BPS-NI, CPOT, NVPS-I, NVPS-R, and PAINAD, when compared with those of the 2018 SCCM clinical practice guidelines. ${ }^{4}$ The BPS, BPS-NI, and the CPOT remain the behavioral pain assessment tools with the strongest psychometric properties, as stated in the 2018 SCCM guidelines. ${ }^{4}$ These tools underwent external validation in several countries (not including Canada and France, where they were originally developed) and have been translated into several different languages. Comparison of the BPS and the CPOT yielded similar psychometric results. ${ }^{18,19,22,31,33,34,37,46-48}$ The BPAT is the tool that was validated in the most countries $(\mathrm{n}=28)$ and is available in multiple languages. Good psychometric findings have been reported for the initial and revised versions of the NVPS for their use in the ICU; however, the physiologic indicators did not perform as well as the behavioral indicators. Similar findings were obtained using the MOPAT, with the behavioral indicators performing better compared with physiologic indicators. Tools developed for pediatric and non-ICU populations would require some adaptation to be valid in the adult ICU population. This strengthens the fact that use of a tool is valid for a specific population and in a given context, ${ }^{98}$ and that use of the tool in a different patient group or context of care is contingent on its additional validation in these new circumstances.

In many studies, a lack of attention to basic assumptions in statistics was noted. The most frequent was the calculation of Cronbach $\alpha$ or correlation coefficients on the basis of the number of observations (eg, 300 observations) within subjects (eg, 30 patients) assessed at different times, which may inflate the values of these coefficients. A more accurate approach is to calculate and report these coefficients using the sample of patients at each assessment time (eg, before, during, and after procedures). A Cronbach $\alpha$ is based on shared variance among items, which may be low when calculated at rest because the tools' scores tend to be low. Cronbach $\alpha$ also is influenced by the number of items (ie, a greater number of items increases the coefficient value). ${ }^{131}$ Therefore, we may question the relevance of this statistic for the validation of behavioral pain assessment tools.

Confusion regarding validation strategies was also noted. In several studies, authors reported a correlation coefficient between the scores of 2 scales with similar items (eg, BPS and CPOT) and described this strategy as convergent or a criterion validation. Convergent validation refers to comparing 2 different assessment methods measuring the same concept (in this review, the concept is related to pain behaviors). Using similar assessment methods (eg, 2 behavioral pain assessment tools), therefore, is not the most useful approach, because the correlation tends to be high $(>0.80)$, as reported in studies $^{18,19,22,31,33-35,37,46-48,83,95,118}$ included in this review. 
The use of other pain-related measures such as pain distress ${ }^{14}$ or pain unpleasantnes ${ }^{85}$ would be more appropriate for convergent validation testing. Criterion validation refers to comparing the tool with the gold standard established in the field. ${ }^{98}$ The patient's selfreport is the gold standard criterion in the field of pain. Therefore, using 2 behavioral pain assessment tools for criterion validation is not appropriate.

ROC analysis is a common strategy to establish the performance of a test or tool to detect a problem as well as sensitivity and specificity associated with the best cut-point score. ${ }^{132} \mathrm{~A}$ gold standard criterion must be present that allows discrimination of patients into 2 groups: 1 with pain and 1 without pain. Because behavioral pain assessment tools are developed for use with noncommunicative patients in the ICU, cut-point scores for these tools were established in most studies using the self-report of communicative patients in the ICU. ${ }^{11,21,32,33,37,58,61,66,68,75,78,92,99}$ Although it may represent the best available approach according to the pain definition, this strategy may have limitations because the patient's self-report of pain must be reliable and is influenced by many personal and social factors. Delirium is a common source of unreliable self-report, and screening for delirium was not specified in many studies. Moreover, this approach may be appropriate if we assume that pain behaviors are the same in communicative and noncommunicative patients in the ICU. The level of consciousness and the level of sedation or agitation may influence pain behaviors. The threshold could be lower in patients with a low level of consciousness or a high level of sedation $^{40}$ or higher in agitated patients. ${ }^{67}$ Another approach was explored by some research teams who used nociceptive procedures as the reference criterion in comparison with rest before a procedure or used nonnociceptive procedures to assess the ability of behavioral tools to detect pain. ${ }^{40,127}$ \{AQ29\} However, not all patients experience pain during nociceptive procedures; therefore, the cut-point score instead would detect a nociceptive procedure (or nociception) than detect pain per se. For consistency in scoring criterion validation, we gave scores to studies in which the patient's self-report of pain was used as the gold standard. In future research, both criteria (ie, self-report of pain, nociceptive procedures) could be explored in ROC analysis to allow comparison between cut-point scores.

In the 2013 SCCM clinical practice guidelines, ${ }^{8}$ validation of behavioral pain assessment tools in patients with brain injury in the ICU was identified as an area for additional research. Since then, this patient group was specifically examined in several studies with the BPS, ${ }^{17,40-45}$ the CPOT, ${ }^{42,91-96}$ the NCS-R, ${ }^{127,129}$ and the NCS-R-I. ${ }^{40}$ In most studies, only the total scale scores were provided. When compared with patients undergoing surgery and those with trauma, those with a brain injury had lower CPOT scores. ${ }^{79}$ Interestingly, a low effect size was found for the facial expression item of the BPS, ${ }^{45}$ and a grimace score of 2 and muscle rigidity score of 2 on the CPOT were not frequently observed..$^{92}$ In addition, specific behaviors such as orbit tightening and eye weeping were described in patients with brain injury in the ICU. ${ }^{133,134}$ Adaptation of the content of existing scales for such patients could enhance their applicability and validity in this vulnerable group.

Potential sources of bias in conducting this analysis include the selection and weighting of items in the psychometric scoring system that influenced the scores of each scale. Also, psychometric properties are not static and may evolve with further development or adaptation and validation testing of a scale. The use of a different system would lead to different scores for each scale. Psychometric scores also were established for the use in scales for adult patients in the ICU. Therefore, they do not reflect the psychometric performance of their use in other contexts of care.

\section{Implications for Nursing}

Nurses play a key role in the assessment and management of pain, and they are advocates for their patients to ensure that pain does not go unnoticed. They are responsible for regularly assessing pain using methods appropriate to a patient's ability to communicate and to offer adequate treatment based on a multimodal analgesic approach. Behavioral pain scores as part of pain management algorithms $\mathrm{s}^{3,23,52}$ may guide nurses in the administration of a low opioid dose when appropriate, and pain reassessment is essential to evaluate the effectiveness of analgesia and adjust the treatment. Nurses can also 
initiate nonpharmacologic interventions to optimize pain management. ${ }^{4}$ Family members can be consulted about pain-related behaviors of their loved one and offered the opportunity to contribute to pain management if they feel comfortable doing so. ${ }^{4-6}$

Pain management is a team effort and, to optimize the nurse's role in pain management, training on any tool's use should be offered to all members of the multidisciplinary team. Communication about pain assessment and management would be enhanced if addressed during nursing handoffs and multidisciplinary daily rounds, with all attendees understanding the methods used for obtaining crucial information about the patient's pain. In addition, ICU leaders, such as clinical nurse specialists or educators, are encouraged to conduct routine quality control on the use of pain assessment tools by clinicians so accurate information is used to make treatment decisions.

\section{Future Research Steps}

Implementation studies have focused mainly on pain management practice indicators and short-term patient outcomes. Still unexplored, however, is the impact pain management protocols based on the regular use of pain assessment tools have on long-term patient outcomes, such as chronic pain development and quality of life. In addition,

behavioral pain assessment tools can only be used in patients able to behaviorally react to stimulation. Therefore, they are minimal or absent in patients who are heavily sedated (eg, RASS of -4) and are not observable in unresponsive patients (eg, Glasgow Coma Scale score of 3; RASS of -5). Behavioral pain assessment tools can also be challenging to use in very agitated patients. ${ }^{67}$ In such situations, clinicians can consider that a patient might be in pain if a responsive patient in a similar condition would most likely report pain, and alternative assessment methods must be explored. Although vital signs are not valid for pain assessment purposes in the ICU when considered individually, ${ }^{3-6}$ innovative technology may have some potential. The use of the Analgesia Nociception Index (which is based on heart rate variability) and the Nociception Level Index (which is based on multiple parameters related to heart rate, heart rate variability, galvanic skin response, and peripheral temperature) have been studied for ICU pain assessment, ${ }^{42,135,136}$ but more research is needed.

\section{Conclusions}

The use of validated behavioral pain assessment tools is crucial for noncommunicative patients in the ICU. The BPS, BPS-NI, and CPOT, which were specifically developed for this population, have shown the strongest psychometric properties with highest evidence; their use is feasible and positively influenced pain management practices and patient outcomes. It is important that all members of the multidisciplinary team be trained to use the behavioral pain assessment tool selected for their ICU setting so they can interpret pain scores and better communicate about pain assessment findings. Assessing pain properly is the key step to improved pain management and better care for noncommunicative patients in the ICU.

\section{REFERENCES}

1. Chanques G, Sebbane M, Barbotte E, Viel E, Eledjam JJ, Jaber S. A prospective study of pain at rest: incidence and characteristics of an unrecognized symptom in surgical and trauma versus medical intensive care unit patients. Anesthesiology. 2007;107(5):858-860.

2. Puntillo KA, Max A, Timsit JF, et al. Determinants of procedural pain intensity in the intensive care unit: the Europain study. Am J Respir Crit Care Med. 2014;189(1):39-47.

3. Gélinas C. Pain assessment in the critically ill adult: recent evidence and new trends. Intensive Crit Care Nurs. 2016;34:1-11.

4. Devlin JW, Skrobik Y, Gélinas C, et al. Clinical practice guidelines for the prevention and management of pain, agitation/sedation, delirium, immobility, and sleep disruption in adult patients in the ICU. Crit Care Med. 2018;46(9):e825-e873. doi:10.1097 /CCM.0000000000003299

5. Clinical Resources Task Force, American Asssociation of Critical-Care Nurses. Assessing pain in critically ill adults. Crit Care Nurs. 2018;38(6):e13-e16.

6. Herr K, Coyne PJ, McCaffery M, Manworren R, Merkel S. Pain assessment in the patient unable to self-report: position statement with clinical practice recommendations. Pain Manag Nurs. 2011;12(4):230-250.

7. Gélinas C, Puntillo KA, Joffe AM, Barr J. A validated approach to evaluating psychometric properties of pain assessment tools for use in nonverbal critically ill adults. Semin Respir Crit Care Med. 2013;34(2):153-168.

8. Barr J, Fraser GL, Puntillo K, et al. Clinical practice guidelines for the management of pain, agitation, and delirium in adult patients in the intensive care unit. Crit Care Med. 2013;41(1):263-306.

9. Devlin JW, Skrobik Y, Rochwerg B, et al. Methodologic innovation in creating clinical practice guidelines: insights from the 2018 Society of Critical Care Medicine pain, agitation/sedation, delirium, immobility, and sleep disruption guideline effort. Crit Care Med. 2018;46(9):1457-1463.

10. Puntillo KA, Morris AB, Thompson CL, Stanik-Hutt J, White CA, Wild LR. Pain behaviors observed during six common procedures: results from Thunder Project II. Crit Care Med. 2004;32(2):421-427. 
11. McGrath P, Johnson G, Goodman J, Dunn J, Chapman J. CHEOPS: a behavioral scale for rating postoperative pain in children. In: Field HL, Dubner R, Cervero R, eds. Advances for Pain Research and Therapy. Vol 9. New York, NY: Raven; 1985:395-402.

12. Puntillo KA, Miaskowski C, Kehrle K, Stannard D, Gleeson S, Nye P. Relationship between behavioral and physiological indicators of pain, critical care patients' self-reports of pain, and opioid administration. Crit Care Med. 1997;25(7):1159-1166.

13. Li D, Miaskowski C, Burkhardt D, Puntillo K. Evaluations of physiologic reactivity and reflexive behaviors during noxious procedures in sedated critically ill patients. J Crit Care. 2009;24(3):472.e9-472.e13. doi:10.1016/j.jcrc.2008.07.005

14. Gélinas C, Puntillo KA, Levin P, Azoulay E. The behavior pain assessment tool for critically ill adults: a validation study in 28 countries. Pain. 2017;158(5):811-821.

15. Chanques G, Payen JF, Mercier G, et al. Assessing pain in non-intubated critically ill patients unable to self report: an adaptation of the Behavioral Pain Scale. Intensive Care Med. 2009;35(12):2060-2067.

16. Payen JF, Bru O, Bosson JL, et al. Assessing pain in critically ill sedated patients by using a behavioral pain scale. Crit Care Med. 2001;29(12):2258-2263.

17. Azevedo-Santos IF, Alves IG, Badaue-Passos D, Santana-Filho VJ, DeSantana JM. Psychometric analysis of behavioral pain scale Brazilian version in sedated and mechanically ventilated adult patients: a preliminary study. Pain Pract. 2016;16(4):451-458.

18. Klein C, Caumo W, Gélinas C, et al. Validation of two pain assessment tools using a standardized nociceptive stimulation in critically ill adults. J Pain Symptom Manage. 2018;56(4):594-601.

19. Rijkenberg S, Stilma W, Endeman H, Bosman RJ, Oudemans-van Straaten HM. Pain measurement in mechanically ventilated critically ill patients: Behavioral Pain Scale versus Critical-Care Pain Observation Tool. $J$ Crit Care. 2015;30(1):167-172.

20. Carletti S AC, Rossi E, Destrebecq A, Terzoni S, Bonetti $\mathrm{L}$. Translation and validation in Italian of the behavioral pain scale non-intubated patients (BPS-NI) for pain assessment in non-intubated critically ill patients, unable to self-report [in Italian]. Scenario. 2016;33(1):4-13.

21. Chen YY, Lai YH, Shun SC, Chi NH, Tsai PS, Liao YM The Chinese Behavior Pain Scale for critically ill patients: translation and psychometric testing. Int $\mathrm{J}$ Nurs Stud. 2011;48(4):438-448

22. Hsiung NH, Yang $Y$, Lee MS, Dalal K, Smith GD. Translation, adaptation, and validation of the behavioral pain scale and the critical-care pain observational tools in Taiwan. J Pain Res. 2016;9:661-669.

23. Olsen BF, Rustoen T, Sandvik L, Miaskowski C, Jacobsen $M$, Valeberg BT. Development of a pain management algorithm for intensive care units. Heart Lung. 2015;44(6):521-527.

24. Gutysz-Wojnicka A, Ozga D, Mayzner-Zawadzka E, Dyk D, Majewski M, Doboszynska A. Psychometric assessment of physiologic and behavioral pain indicators in Polish versions of the pain assessment scales. Pain Manag Nurs. 2019;20(3):292-301.

25. Hylén M, Akerman E, Alm-Roijer C, Idvall E. Behavioral Pain Scale - translation, reliability, and validity in a Swedish context. Acta Anaesthesiol Scand. 2016;1(6):821-828.

26. Wild D, Grove A, Martin M, et al. Principles of good practice for the translation and cultural adaptation process for patient-reported outcomes (PRO) measures: report of the ISPOR Task Force for Translation and $\mathrm{Cul}$ tural Adaptation. Value Health. 2005;8(2):94-104.

27. Chen J, Lu Q, Wu XY, An YZ, Zhan YC, Zhang HY. Reliability and validity of the Chinese version of the behavioral pain scale in intubated and non-intubated critically ill patients: two cross-sectional studies. Int $J$ Nurs Stud. 2016;61:63-71.

28. Ahlers SJ, van Gulik L, van der Veen AM, et al. Comparison of different pain scoring systems in critically ill patients in a general ICU. Crit Care. 2008;1(1):R15.

29. Ahlers SJ, van der Veen AM, van Dijk M, Tibboel D, Knibbe CA. The use of the Behavioral Pain Scale to assess pain in conscious sedated patients. Anesth Analg. 2010;110(1):127-133.

30. Aissaoui Y, Zeggwagh AA, Zekraoui A, Abidi K, Abouqal $R$. Validation of a behavioral pain scale in critically ill, sedated, and mechanically ventilated patients. Anesthes Analg. 2005;101(5):1470-1476.

31. Al Darwish ZQ, Hamdi R, Fallatah S. Evaluation of pain assessment tools in patients receiving mechanical ventilation. AACN Adv Crit Care. 2016;27(2):162-172.

32. Bouajram RH, Sebat CM, Love D, Louie EL, Wilson MD, Duby JJ. Comparison of self-reported and behavioral pain assessment tools in critically ill patients [published online February 1, 2018]. J Intensive Care Med. doi:10.1177/0885066618757450

33. Cheng L-H, Tsai Y-F, Wang C-H, Tsay P-K. Validation of two Chinese-version pain observation tools in conscious and unconscious critically ill patients. Intensive Crit Care Nurs. 2018;44:115-122.

34. Gomarverdi S, Sedighie L, Seifrabiei MA, Nikooseresht M. Comparison of two pain scales: Behavioral Pain Scale and Critical-Care Pain Observation Tool during invasive and noninvasive procedures in intensive care unit-admitted patients. Iran J Nurs Midwifery Res. 2019;24(2):151-155.

35. Juarez $\mathrm{P}$, Bach $\mathrm{A}$, Baker $\mathrm{M}$, et al. Comparison of two pain scales for the assessment of pain in the ventilated adult patient. Dimens Crit Care Nurs. 2010;29(6):307-315.

36. Rahu MA, Grap MJ, Ferguson P, Joseph P, Sherman S, Elswick RK. Validity and sensitivity of 6 pain scales in critically ill, intubated adults. Am J Crit Care. 2015;24(6):514-523.

37. Severgnini P, Pelosi P, Contino E, Serafinelli E, Novario $\mathrm{R}$, Chiaranda M. Accuracy of Critical Care Pain Observation Tool and Behavioral Pain Scale to assess pain in critically ill conscious and unconscious patients: prospective, observational study. J Intensive Care. 2016;4:68

38. Young J, Siffleet J, Nikoletti S, Shaw T. Use of a Behavioural Pain Scale to assess pain in ventilated, unconscious and/or sedated patients. Intensive Crit Care Nurs. 2006;22(1):32-39.

39. Navarro-Colom M, Sendra-Lluis MA, Castillo-Masa AM, Robleda G. Intraobserver reliability and internal consistency of the Behavioral Pain Scale in mechanically-ventilated patients [in Spanish]. Enferm Intensiva. 2015;26(1):24-31.

40. Bernard C, Delmas V, Duflos C, et al. Assessing pain in critically ill brain-injured patients: a psychometric comparison of 3 pain scales and videopupillometry. Pain. 2019;10:10.

41. Dehghani $H$, Tavangar $H$, Ghandehari A. Validity and reliability of behavioral pain scale in patients with low level of consciousness due to head trauma hospitalized in intensive care unit. Arch Trauma Res. 2014;3(1):e18608. doi:10.5812/atr.18608

42. Jendoubi A, Abbes A, Ghedira S, Houissa M. Pain measurement in mechanically ventilated patients with traumatic brain injury: behavioral pain tools versus analgesia nociception index. Indian J Crit Care Med. 2017;21(9):585-588.

43. Ribeiro CJN, Bezerra DS, Lima AGCF, Fernandes CCF, Menezes MGdV, Ribeiro MdCdO. Pain during tracheal aspiration in patients with traumatic brain injury undergoing mechanical ventilation. Revista Dor. 2017;18:332-337.

44. Ribeiro CJN, Araujo ACS, Brito SB, et al. Pain assessment of traumatic brain injury victims using the 
Brazilian version of the Behavioral Pain Scale. Rev Bras Ter Intensiva. 2018;30(1):42-49.

45. Ribeiro CJN, Lima A, de Araujo RAS, et al. Psychometric properties of the behavioral pain scale in traumatic brain injury. Pain Manag Nurs. 2019;20(2):152-157.

46. Chanques G, Pohlman A, Kress JP, et al. Psychometric comparison of three behavioural scales for the assessment of pain in critically ill patients unable to selfreport. Crit Care. 2014;18(5):R160.

47. Liu Y, Li L, Herr K. Evaluation of two observational pain assessment tools in Chinese critically ill patients. Pain Med. 2015;16(8):1622-1628.

48. Rijkenberg S, Stilma W, Bosman RJ, van der Meer NJ, van der Voort PHJ. Pain measurement in mechanically ventilated patients after cardiac surgery: comparison of the Behavioral Pain Scale (BPS) and the Critical-Care Pain Observation Tool (CPOT). J Cardiothorac Vasc Anesth. 2017;31(4):1227-1234.

49. Chanques G, Jaber S, Barbotte E, et al. Impact of systematic evaluation of pain and agitation in an intensive care unit. Crit Care Med. 2006;34(6):1691-1699.

50. Radtke FM, Heymann A, Franck M, et al. How to implement monitoring tools for sedation, pain and delirium in the intensive care unit: an experimental cohort study. Intensive Care Med. 2012;38(12):1974-1981.

51. Williams TA, Martin S, Leslie G, et al. Duration of mechanical ventilation in an adult intensive care unit after introduction of sedation and pain scales. $\mathrm{Am} \mathrm{J}$ Crit Care. 2008;17(4):349-356.

52. de Jong A, Molinari N, de Lattre S, et al. Decreasing severe pain and serious adverse events while moving intensive care unit patients: a prospective interventional study (the NURSE-DO project). Crit Care. 2013;17(2):R74.

53. Olsen BF, Rustoen T, Sandvik L, Miaskowski C, Jacobsen $M$, Valeberg BT. Implementation of a pain management algorithm in intensive care units and evaluation of nurses' level of adherence with the algorithm. Heart Lung. 2015;44(6):528-533.

54. Olsen BF, Rustoen T, Sandvik L, Jacobsen M, Valeberg BT. Results of implementing a pain management algorithm in intensive care unit patients: the impact on pain assessment, length of stay, and duration of ventilation. J Crit Care. 2016;36:207-211.

55. Gélinas C. Développement et validation d'une grille d'observation clinique de la douleur auprès d'une clientèle adulte de soins critiques présentant ou non une altération du niveau de conscience (Tome 1 et Tome 2) [dissertation]. Québec, QC, Canada: Université Laval; 2004. \{AQ30\}

56. Gélinas C, Fillion L, Puntillo KA, Viens C, Fortier M. Validation of the Critical-Care Pain Observation Tool in adult patients. Am J Crit Care. 2006;15(4):420-427.

57. Gélinas C, Fillion L, Puntillo KA. Item selection and content validity of the Critical-Care Pain Observation Tool for non-verbal adults. J Adv Nurs. 2009;65(1):203-216.

58. Gélinas C, Johnston C. Pain assessment in the critically ill ventilated adult: validation of the Critical-Care Pain Observation Tool and physiologic indicators. Clin J Pain. 2007;23(6):497-505.

59. Gélinas C, Rémy J, Gagné L, Desjardins S, Chabot MP, Vaillant F. Le CPOT - Évaluer la douleur de patients adultes inconscients. Perspective Infirmière. 2015;12(2):48-53. \{AQ30\}

60. Gélinas $C$. Nurses' evaluations of the feasibility and the clinical utility of the Critical-Care Pain Observation Tool. Pain Manag Nurs. 2010;11(2):115-125.

61. Frandsen JB, O'Reilly Poulsen KS, Laerkner E, Stroem T. Validation of the Danish version of the Critical Care Pain Observation Tool. Acta Anaesthesiol Scand. 2016;60(9):1314-1322.

62. Stilma W, Rijkenberg S, Feijen HM, Maaskant JM, Endeman $\mathrm{H}$. Validation of the Dutch version of the
Critical-Care Pain Observation Tool. Nurs Crit Care. 2019;24(3):132-140.

63. Emsden C, Schafer UB, Denhaerynck K, Grossmann F, Frei IA, Kirsch M. Validating a pain assessment tool in heterogeneous ICU patients: is it possible? Nurs Crit Care. 2019:09:09.

64. Mamoura K. Validation of the Greek Version of the Critical Care Observation Tool [master's thesis]. Athens, Greece: National and Kapodistrian University of Athens; 2017.

65. Yamada S, Ikematsu Y. Reliability, validity and responsiveness about the Japanese version of the CriticalCare Pain Observation Tool (CPOT-J). J Jpn Soc Intensive Care Med. 2016;23(2):133-140.

66. Kwak EM, Oh H. Validation of a Korean translated version of the Critical Care Pain Observation Tool (CPOT) for ICU patients [in Korean]. J Korean Acad Nurs. 2012;42(1):76-84.

67. Chookalayia $\mathrm{H}$, Heidarzadeh $\mathrm{M}$, Hassanpour-Darghah M, Aghamohammadi-Kalkhoran M, Karimollahi M. The Critical Care Pain Observation Tool is reliable in nonagitated but not in agitated intubated patients. Intensive Crit Care Nurs. 2018;44:123-128.

68. Kotfis K, Zegan-Baranska M, Strzelbicka M, et al. Validation of the Polish version of the Critical Care Pain Observation Tool (CPOT) to assess pain intensity in adult, intubated intensive care unit patients: the POLCPOT study. Arch Med Sci. 2018;14(4):880-889.

69. Nürnberg Damstrom D, Saboonchi F, Sackey PV, Bjorling $\mathrm{G}$. A preliminary validation of the Swedish version of the Critical-Care Pain Observation Tool in adults. Acta Anaesthesiol Scand. 2011:55(4):379-386.

70. Aktas YY, Karabulut N. A Turkish version of the Critical-Care Pain Observation Tool: reliability and validity assessment. J Perianesth Nurs. 2017;32(4):341-351.

71. Vazquez M, Pardavila MI, Lucia M, Aguado Y, Margall MA, Asiain MC. Pain assessment in turning procedures for patients with invasive mechanical ventilation. Nurs Crit Care. 2011;16(4):178-185.

72. Stefani F, Nardon G, Bonato R, Modenese A, Novello C, Ferrari R. The validation of C-POT (Critical-Care Pain Observation Tool) scale: a tool for assessing pain in intensive care patients [in Italian]. Assist Inferm Ric. 2011;30(3):135-143.

73. Pudas-Tahka SM, Axelin A, Aantaa R, Lund V, Salantera S. Translation and cultural adaptation of an objective pain assessment tool for Finnish ICU patients. Scand J Caring Sci. 2014;28(4):885-894.

74. Storsveen A-M, Hall-Lord M-L. The CPOT-a tool for pain assessment for intensive care patients. 2016. https://sykepleien.no/node/61578.

75. Li Q, Wan X, Gu C, et al. Pain assessment using the Critical-Care Pain Observation Tool in Chinese critically ill ventilated adults. J Pain Symptom Manage. 2014;48(5):975-982.

76. Buttes P, Keal G, Cronin SN, Stocks L, Stout C. Validation of the Critical-Care Pain Observation Tool in adult critically ill patients. Dimens Crit Care Nurs. 2014;33(2):78-81.

77. Chen J, Hu F, Yang J, et al. Validation of a Chinese version Critical-Care Pain Observation Tool in nonintubated and intubated critically ill patients: two cross-sectional studies. J Clin Nurs. 2019;28(15-16):2824-2832.

78. Dale CM, Prendergast V, Gélinas C, Rose L. Validation of The Critical-Care Pain Observation Tool (CPOT) for the detection of oral-pharyngeal pain in critically ill adults. J Crit Care. 2018:48:334-338.

79. Gélinas C, Arbour C. Behavioral and physiologic indicators during a nociceptive procedure in conscious and unconscious mechanically ventilated adults: similar or different? J Crit Care. 2009;24(4):628.e627-617.

80. Gélinas $C$, Tousignant-Laflamme $Y$, Tanguay A, Bourgault $P$. Exploring the validity of the bispectral index, the Critical-Care Pain Observation Tool and vital signs 
for the detection of pain in sedated and mechanically ventilated critically ill adults: a pilot study. Intensive Crit Care Nurs. 2011;27(1):46-52.

81. Kanji S, MacPhee H, Singh A, et al. Validation of the Critical Care Pain Observation Tool in critically ill patients with delirium: a prospective cohort study. Crit Care Med. 2016;44(5):943-947.

82. Khanna P, Pandey RK, Chandralekha C, Sharma A, Pangasa N. Comparison between Critical-Care Pain Observation Tool and physiologic indicators for pain assessment in the critically ill, mechanically ventilated adult patients. Saudi J Anaesth. 2018;12(3):384-388.

83. Paulson-Conger M, Leske J, Maidl C, Hanson A, Dziadulewicz L. Comparison of two pain assessment tools in nonverbal critical care patients. Pain Manag Nurs. 2011;12(4):218-224.

84. Ross M, Boitor M, Gélinas C. Validation of the CriticalCare Pain Observation Tool with seriously ill patients. J Hosp Palliat Nurs. 2016;18(5):413-420.

85. Boitor M, Fiola JL, Gélinas C. Validation of the CriticalCare Pain Observation Tool and vital signs in relation to the sensory and affective components of pain during mediastinal tube removal in postoperative cardiac surgery intensive care unit adults. J Cardiovasc Nurs. 2016;31(5):425-432.

86. Faritous $Z$, Barzanji A, Azarfarin R, et al. Comparison of bispectral index monitoring with the Critical-Care Pain Observation Tool in the pain assessment of intubated adult patients after cardiac surgery. Anesth Pain Med. 2016;6(4):e38334.

87. Ghanbari A, Bahadorizadeh N, Farmanbar R, Kazemnejad E. Sensitivity and specificity of Critical Care Pain Observation Tool used for intubated patients following open-heart surgery. Intensive Care Med. 2016;42(4):618-619.

88. Keane KM. Validity and reliability of the critical care pain observation tool: a replication study. Pain Manag Nurs. 2013;14(4):e216-e225.

89. Kiavar M, Azarfarin R, Totonchi Z, Tavakoli F, Alizadehasl A, Teymouri M. Comparison of two pain assessment tools, "Facial Expression" and "Critical Care Pain Observation Tool" in intubated patients after cardiac surgery. Anesth Pain Med. 2016:6(1):e33434.

90. Linde SM, Badger JM, Machan JT, et al. Reevaluation of the Critical-Care Pain Observation Tool in intubated adults after cardiac surgery. Am J Crit Care. 2013;22(6):491-497.

91. Echegaray-Benites C, Kapoustina O, Gélinas C. Validation of the use of the Critical-Care Pain Observation Tool (CPOT) with brain surgery patients in the neurosurgical intensive care unit. Intensive Crit Care Nurs. 2014;30(5):257-265.

92. Joffe AM, McNulty B, Boitor M, Marsh R, Gélinas C. Validation of the Critical-Care Pain Observation Tool in brain-injured critically ill adults. J Crit Care. 2016;36:76-80.

93. Lee K, Oh H, Suh Y, Seo W. Patterns and clinical correlates of pain among brain injury patients in critical care assessed with the critical care pain observation tool. Pain Manag Nurs. 2013;14(4):259-267.

94. Shan K, Cao W, Yuan Y, et al. Use of the Critical-Care Pain Observation Tool and the bispectral index for the detection of pain in brain-injured patients undergoing mechanical ventilation: a STROBE-compliant observational study. Medicine (Baltimore). 2018;97(22):e10985.

95. Sulla F, De Souza Ramos N, Terzi N, et al. Validation of the Italian version of the Critical Pain Observation Tool in brain-injured critically ill adults. Acta Biomed. 2017;88(5S):48-54.

96. Topolovec-Vranic J, Gélinas C, Li Y, et al. Validation and evaluation of two observational pain assessment tools in a trauma and neurosurgical intensive care unit. Pain Res Manag. 2013;18(6):e107-114. doi: $10.1155 / 2013 / 263104$
97. Gélinas $C$. When and how to evaluate interrater reliability of patient assessment tools. AACN Adv Crit Care. 2011:22(4):412-417.

98. Streiner DL, Norman GR, Cairney J. Health Measurement Scales: A Practical Guide to Their Development and Use. 5th ed. New York, NY: Oxford University Press; 2015.

99. Gélinas C, Harel F, Fillion L, Puntillo KA, Johnston CC. Sensitivity and specificity of the Critical-Care Pain Observation Tool for the detection of pain in intubated adults after cardiac surgery. J Pain Symptom Manage. 2009;37(1):58-67.

100. Bourbonnais FF, Malone-Tucker S, Dalton-Kischei D. Intensive care nurses' assessment of pain in patients who are mechanically ventilated: how a pilot study helped to influence practice. Can J Crit Care Nurs. 2016;27(3):24-29.

101. Gélinas $C$, Ross M, Boitor M, Desjardins S, Vaillant F, Michaud C. Nurses' evaluations of the CPOT use at 12-month post-implementation in the intensive care unit. Nurs Crit Care. 2014;19(6):272-280.

102. Asadi-Noghabi AA, Gholizadeh M, Zolfaghari M, Mehran A, Sohrabi M. Nurses use of Critical Care Pain Observational Tool in patients with low consciousness. Oman Med J. 2015;30(4):276-282.

103. Damico V, Cazzaniga F, Murano L, Ciceri R, Nattino G, Dal Molin A. Impact of a clinical therapeutic intervention on pain assessment, management, and nursing practices in an intensive care unit: a before-and-after study. Pain Manag Nurs. 2018;19(3):256-266.

104. Gélinas C, Arbour C, Michaud C, Vaillant F, Desjardins S. Implementation of the Critical-Care Pain Observation Tool on pain assessment/management nursing practices in an intensive care unit with nonverbal critically ill adults: a before and after study. Int J Nurs Stud. 2011;48(12):1495-1504.

105. Phillips ML, Kuruvilla V, Bailey M. Implementation of the Critical Care Pain Observation Tool increases the frequency of pain assessment for noncommunicative ICU patients. Aust Crit Care. 2018;09:09.

106. Mascarenhas $M$, Beattie M, Roxburgh M, MacKintosh J, Clarke N, Srivastava D. Using the Model for Improvement to implement the Critical-Care Pain Observation Tool in an adult intensive care unit. BMJ Open Qual. 2018;7(4):e000304.

107. Rose L, Haslam L, Dale C, Knechtel L, McGillion M. Behavioral pain assessment tool for critically ill adults unable to self-report pain. Am J Crit Care. 2013;22(3):246-255

108. Faust AC, Rajan P, Sheperd LA, Alvarez CA, McCorstin $P$, Doebele RL. Impact of an analgesia-based sedation protocol on mechanically ventilated patients in a medical intensive care unit. Anesthes Analg. 2016;123(4):903-909

109. Arbour C, Gélinas C, Michaud C. Impact of the implementation of the critical-care pain observation tool (CPOT) on pain management and clinical outcomes in mechanically ventilated trauma intensive care unit patients: a pilot study. $J$ Trauma Nurs. 2011;18(1):52-60.

110. Latorre-Marco I, Solís Munoz M, Falero Ruiz T, et al. Validation of the Scale of Behavior Indicators of Pain (ESCID) in critically ill, non-communicative patients under mechanical ventilation: Results of the ESCID scale [in Spanish]. Enferm Intensiva. 2011;22(1):3-12.

111. Erdek MA, Pronovost PJ. Improving assessment and treatment of pain in the critically ill. Int J Qual Health Care. 2004;16(1):59-64

112. Pardo C, Munoz T, Chamorro C, Analgesia and Sedation Work Group of SEMICYUC. Monitoring pain: recommendations of the Analgesia and Sedation Work Group of SEMICYUC [in Spanish]. Med Intensiva. 2006;30(8):379-385

113. Latorre-Marco I, Acevedo-Nuevo M, Solis-Munoz M, et al. Psychometric validation of the behavioral indicators 
of pain scale for the assessment of pain in mechanically ventilated and unable to self-report critical care patients. Med Intensiva. 2016;40(8):463-473.

114. Lopez-Lopez C, Perez-Perez T, Beneit-Montesinos JV, et al. Pain assessment in mechanically ventilated, noncommunicative severe trauma patients. J Trauma Nurs. 2018;25(1):49-59.

115. Klein DG, Dumpe M, Katz E, Bena J. Pain assessment in the intensive care unit: development and psychometric testing of the nonverbal pain assessment tool. Heart Lung. 2010;39(6):521-528.

116. Odhner M, Wegman D, Freeland N, Steinmetz A, Ingersoll GL. Assessing pain control in nonverbal critically ill adults. Dimens Crit Care Nurs. 2003;22(6):260-267.

117. Kabes AM, Graves JK, Norris J. Further validation of the nonverbal pain scale in intensive care patients. Crit Care Nurse. 2009;29(1):59-66.

118. Kaya P, Erden S. Cross-cultural adaptation, validity and reliability of the Turkish version of Revised Nonverbal Pain Scale. Agri. 2019;31(1):15-22.

119. Chookalayi H, Heidarzadeh M, Hasanpour M, Jabrailzadeh S, Sadeghpour F. A study on the psychometric properties of revised-nonverbal pain scale and originalnonverbal pain scale in Iranian nonverbal-ventilated patients. Indian J Crit Care Med. 2017;21(7):429-435.

120. Topolovec-Vranic J, Canzian S, Innis J, PollmannMudryj MA, McFarlan AW, Baker AJ. Patient satisfaction and documentation of pain assessments and management after implementing the adult nonverbal pain scale. Am J Crit Care. 2010;19(4):345-355.

121. Sacco TL, LaRiccia B. Interprofessional implementation of a pain/sedation guideline on a trauma intensive care unit. J Trauma Nurs. 2016;23(3):156-164.

122. Puntillo KA, Stannard D, Miaskowski C, Kehrle K, Gleeson S. Use of a pain assessment and intervention notation (P.A.I.N.) tool in critical care nursing practice: nurses' evaluations. Heart Lung. 2002;31(4):303-314

123. Merkel SI, Voepel-Lewis T, Shayevitz JR, Malviya S. The FLACC: a behavioral scale for scoring postoperative pain in young children. Pediatr Nurs. 1997;23(3):293-297.

124. Voepel-Lewis T, Zanotti J, Dammeyer JA, Merkel S. Reliability and validity of the face, legs, activity, cry, consolability behavioral tool in assessing acute pain in critically ill patients. Am J Crit Care. 2010;19(1):55-61.

125. McGuire DB, Reifsnyder J, Soeken K, Kaiser KS, Yeager KA. Assessing pain in nonresponsive hospice patients: development and preliminary testing of the multidimensional objective pain assessment tool (MOPAT). J Palliat Med. 2011;14(3):287-292.

126. Wiegand DL, Wilson T, Pannullo D, et al. Measuring acute pain over time in the critically ill using the Multidimensional Objective Pain Assessment Tool (MOPAT). Pain Manag Nurs. 2018;19(3):277-287.

127. Chatelle C, Majerus S, Whyte J, Laureys S, Schnakers C. A sensitive scale to assess nociceptive pain in patients with disorders of consciousness. J Neurol Neurosurg Psychiatry. 2012;83(12):1233-1237.

128. Schnakers C, Chatelle C, Vanhaudenhuyse A, et al. The Nociception Coma Scale: a new tool to assess nociception in disorders of consciousness. Pain. 2010;148(2):215-219.

129. Chatelle C, De Val MD, Catano A, et al. Is the nociception coma scale-revised a useful clinical tool for managing pain in patients with disorders of consciousness? Clin J Pain. 2016;32(4):321-326.

130. Warden V, Hurley AC, Volicer L. Development and psychometric evaluation of the Pain Assessment in Advanced Dementia (PAINAD) scale. J Am Med Dir Assoc. 2003;4(1):9-15.

131. Taber KS. The use of Cronbach's alpha when developing and reporting research instruments in science education. Res Sci Educ. 2018;48(6):1273-1296.

132. Fischer JE, Bachmann LM, Jaeschke R. A readers' guide to the interpretation of diagnostic test properties: clinical example of sepsis. Intensive Care Med. 2003;29(7):1043-1051.

133. Gélinas C, Boitor M, Puntillo KA, et al. Behaviors indicative of pain in brain-injured adult patients with different levels of consciousness in the intensive care unit. $J$ Pain Symptom Manage. 2019;57(4):761-773.

134. Roulin MJ, Ramelet AS. Behavioral changes in braininjured critical care adults with different levels of consciousness during nociceptive stimulation: an observational study. Intensive Care Med. 2014;40(8):1115-1123.

135. Gelinas C, Richebe P. Exploring the use of an innovative technology for pain assessment during mediastinal tube removal in cardiac surgery patients in the intensive care unit: the Nociception Level (NOL). Intensive Care Med Experimental. 2018;6(suppl 2):1319.

136. Shahiri S, Richard-Lalonde M, Richebe P, Gelinas C. Exploration of the Nociception Level Index for pain assessment during endotracheal suctioning in mechanically ventilated patients in the intensive care unit. Can J Pain. 2019;3(1):A131.

\section{AUTHOR QUERIES}

The following queries are indicated on your galley pages by a highlighted $\{\mathrm{AQ} 1\}$ or $\{\mathrm{AQ} 2\}$ and so on embedded in the text. Please respond to each query directly on the galley whenever possible, indicating how the galley is to be altered. Other comments or longer changes can be marked on this query sheet and returned with the galleys. Be sure to respond to each query; if OK, mark OK.

\section{AQ1: Per journal style, each author's full} name is used on byline-we supplied these from release forms. Please confirm authors' names and affiliations, and the corresponding author's address are correct.

AQ2: Per journal style, fellowships are not listed in the author byline.

AQ3: Please note there was an affiliation with the footnote number 12 ("School of Nursing, University of California, San Francisco"), but none of the authors' names were marked with footnote 12 , so that was removed. If this affiliation should be retained, please indicate which author is associated with it.

\section{AQ4: Does the edit to the previous sen-} tence preserve your intended meaning?

AQ5: The sentence that began "Three of those tools" was removed from the Abstract because it was an unconditional claim of priority. In the main text, where claims of priority (ie, "for the first time" and similar phrasing) are made, they have been retained but qualified (ie, "to our knowledge" has been added). Edit OK?

AQ6: Is the edit to the previous sentence correct? 
AQ7: As done for the first author, please indicate each author's role at their listed affiliation(s). XXX has been used as a placeholder where this information should be supplied.

AQ8: Does the edit to the previous sentence preserve your intent? OK?

AQ9: Is the edit to the previous sentence

AQ10: Do the edits to the previous sentence preserve your intent?

AQ11: Please confirm the abbreviation ESCID was expanded correctly in the previous sentence.

AQ12: After discussion with Mary Fran, we'd like to make current Tables 2 and 3 online content, both for space and because they contain supplemental information. We would like to make them Appendices A and B (this would also allow us to avoid having to renumber references throughout to match our style--currently refs in tables are not numbered sequentially within content call-out).

AQ13: In the original manuscript, reference 27 was cited before reference 26 ; therefore, those entries were switched in References and their in-text citations also were switched, so original reference 27 is now reference 26 and vice versa.

AQ14: Do the edits to the previous sentence preserve your intent?

AQ15: References 47 and 48 were cited in the text before reference 46 ; therefore, these entries were rearranged in References to be listed in the order they are cited, and their in-text citations also have been renumbered.

AQ16: The phrases in the previous sentence were rearranged from the original version. Does the edit retain your intended meaning?

AQ17: Does the edit to the previous sentence preserve your intent?

AQ18: OK to add "thresholds" in previous sentence? Please specify what "those" refers to, if that isn't correct.

AQ19: In the previous sentence, please confirm "decrease in mortality" referred to "mortality rate," as edited, rather than "mortality risk" or other term.

AQ20: Is the edit to the previous sentence correct?

AQ21: In the previous sentence, please confirm "it" was identified correctly as "the training" rather than "the CPOT."
AQ22: Does the edit to the previous sentence preserve your intent?

AQ23: Throughout the article, all instances of "ESCID scale" were changed to "ESCID" because the acronym includes the word "scale" (in Spanish).

AQ24: Edit OK to the previous sentence?

AQ25: Is the edit correct to the previous sentence?

AQ26: In the previous sentence, is the edit correct that indicates the range of ICC values refers to the English version of the NVPS-R?

AQ27: In the previous sentence, is the edit correct?

AQ28: In the previous sentence, is the edit correct assuming the statement was still referring to reference 126 ?

AQ29: Does the edit to the previous sentence preserve your intent?

AQ30: Please provide English translation of title. 
Name

Behavior

Assessment

Tool (BOT)

\section{N Items}

Items

Item Score Total Score Cut-Off Score

38 Facial responses: grimace, frown, wince, Yes/No 0 to 38 Not established eyes closed, eyes wide open with eye-

brows raised, looking away in opposite

direction of pain, grin/smile, mouth

wide open to expose teeth and tongue,

clenched teeth exposing slightly open

mouth

Verbal responses: moaning, screaming,

whimpering, crying, using protest

words, verbal complaints of pain

Body movement: no movement, rigid, arching, clenched fists, shaking, with-

drawing, splinting, flailing, picking/

touching site, restlessness, rubbing/

massaging, repetitive movements,

defensive grabbing, pushing, guarding

Behavior Pain

Assessment

Tool (BPAT)

Behavioral Pain

Scale (BPS)

Behavioral Pain

Scale-

Nonintubated

(BPS-NI)

Critical-Care Pain

Observation

Tool (CPOT)

ESCID Behavioral

Indicators of

Pain Scale
8 Neutral expression, grimace, wince, eyes closed, moaning, verbal complaints of pain, rigid, clenched fists

3 Facial expression, movements with upper limbs, compliance with ventilator (BPS), vocalization (BPS-NI)
Yes/No 0 to $8 \quad$ Pain $>3$

1 to $4 \quad 3$ to $12 \quad$ Pain $>5$
4 Facial expression, body movements,

0 to 2

0 to 8

Pain $>3$

muscle tension, compliance with ventilator $\mathbf{O R}$ vocalization

5 Face, restlessness, muscle tone, compliance with ventilator, consolability

\begin{tabular}{|c|c|c|}
\hline 0 to 2 & 0 to 10 & $\begin{array}{l}\text { Not established } \\
0=\text { No pain } \\
1-3=\text { Mild } \\
4-6=\text { Moderate } \\
>7=\text { Severe }\end{array}$ \\
\hline
\end{tabular}

0 to 2

0 to 10 Not established

0 to 2
Face, Legs,

Activity, Cry,

Consolability (FLACC)
Multidimensional

Objective Pain

Assessment

Tool (MOPAT)

5 Face, legs, activity, cry, consolability

8 Behavioral dimension:

Facial expression, restlessness, muscle tension, patient sounds

Physiologic dimension:

Blood pressure, heart rate, respiratory rate, diaphoresis

\section{Nociception}

Coma Scale-

Revised (NCS-R)

Nociception

Coma Scale-

Revised-

Intubated

(NCS-R-I)
Nonverbal Pain

Assessment

Tool (NPAT)
3 Facial expression response, motor response, verbal response (NCS-R), compliance with ventilator (NCS-R-I)

0 (none) to 0 to $16 \quad$ Not established
3 (severe)
0 (no
change)
1 (change)

0 to 3

0 to 9

Pain $>4$

Emotion, movement, verbal cues, facial
cues, positioning/guarding




\section{Table 1: Continued}

\begin{tabular}{|c|c|c|c|c|c|}
\hline Name & N Items & Items & Item Score & Total Score & Cut-Off Score \\
\hline $\begin{array}{c}\text { Nonverbal Pain } \\
\text { Scale (NVPS) }\end{array}$ & 5 & $\begin{array}{l}\text { Behavioral indicators: } \\
\text { Face, activity (movement), guarding } \\
\text { Physiologic indicators: I-vital signs, } \\
\text { Il-skin }\end{array}$ & 0 to 2 & 0 to 10 & Not established \\
\hline $\begin{array}{l}\text { Nonverbal Pain } \\
\text { Scale-Revised } \\
\text { (NVPS-R) }\end{array}$ & 5 & $\begin{array}{l}\text { Behavioral indicators: Face, activity } \\
\text { (movement), guarding } \\
\text { Physiologic indicators: Vital signs, res- } \\
\text { piratory-respiratory rate/oxygen satu- } \\
\text { ration, compliance with ventilator }\end{array}$ & 0 to 2 & 0 to 10 & Not established \\
\hline $\begin{array}{l}\text { Pain Assessment } \\
\text { Intervention } \\
\text { Notation (PAIN) }\end{array}$ & 9 & $\begin{array}{l}\text { Behavioral dimension: movements, } \\
\text { vocalization, facial indicators, and pos- } \\
\text { turing/guarding } \\
\text { Physiological dimension: heart rate, } \\
\text { blood pressure, respiratory rate, per- } \\
\text { spiration, pallor }\end{array}$ & Yes/No & & Not established \\
\hline $\begin{array}{l}\text { Pain Assessment } \\
\text { in Advanced } \\
\text { Dementia } \\
\text { (PAINAD) }\end{array}$ & 5 & $\begin{array}{l}\text { Breathing, negative vocalization, facial } \\
\text { expression, body language, } \\
\text { consolability }\end{array}$ & 0 to 2 & 0 to 10 & $\begin{array}{l}\text { Not established } \\
\text { using gold } \\
\text { standard } \\
\text { As per the } \\
\text { author's } \\
\text { description: } \\
0=\text { No pain } \\
1-3=\text { Mild } \\
4-6=\text { Moderate } \\
7-10=\text { Severe }\end{array}$ \\
\hline
\end{tabular}




\begin{tabular}{|c|c|c|c|c|c|c|c|c|c|c|c|c|c|}
\hline Author & Year & Country & Tool & $\begin{array}{l}\text { Language } \\
\text { Version }\end{array}$ & ICU Clientele/Sample & $\begin{array}{l}\text { Able to } \\
\text { Self- } \\
\text { Report }\end{array}$ & $\begin{array}{l}\text { Unable } \\
\text { to Self- } \\
\text { Report }\end{array}$ & $\begin{array}{c}\text { Internal } \\
\text { Consist- } \\
\text { ency }\end{array}$ & $\begin{array}{c}\text { Interrater } \\
\text { Reliabil- } \\
\text { ity }\end{array}$ & $\begin{array}{l}\text { Content } \\
\text { Valida- } \\
\text { tion }\end{array}$ & $\begin{array}{c}\text { Criterion } \\
\text { Valida- } \\
\text { tion }\end{array}$ & $\begin{array}{l}\text { Discrimina- } \\
\text { tive } \\
\text { Validation } \\
\end{array}$ & Procedure/Treatment \\
\hline $\begin{array}{l}\text { Cheng } \\
\text { et }\left.a\right|^{33}\end{array}$ & 2018 & China & $\begin{array}{l}\text { BPS } \\
\text { CPOT }\end{array}$ & Chinese & 316 medical & $x$ & $x$ & & $x$ & & $x$ & $x$ & ET suctioning, NIBP \\
\hline $\begin{array}{l}\text { Chookalayi } \\
\text { et al }{ }^{119}\end{array}$ & 2017 & Iran & $\begin{array}{l}\text { NVPS } \\
\text { NVPS-R }\end{array}$ & $\begin{array}{l}\text { Translated } \\
\text { but lan- } \\
\text { guage NM }\end{array}$ & $\begin{array}{l}60 \text { mixed dx (medical, } \\
\text { surgical, trauma, } \\
\text { neurological) }\end{array}$ & $x$ & $x$ & $x$ & $x$ & & $\mathrm{x}$ & $\mathrm{x}$ & $\begin{array}{l}\text { Turning, washing eyes with } \\
\text { normal saline }\end{array}$ \\
\hline $\begin{array}{l}\text { Chookalayia } \\
\text { et al }{ }^{67}\end{array}$ & 2018 & Iran & СРОТ & Persian & $\begin{array}{l}65 \text { medical, surgical, } \\
\text { and trauma }\end{array}$ & $x$ & $x$ & $x$ & $x$ & & $x$ & $x$ & Changing position, washing eyes \\
\hline $\begin{array}{l}\text { Dale } \\
\text { et } \mathrm{al}^{78}\end{array}$ & 2018 & Canada & СРОТ & English & $\begin{array}{l}98 \text { medical, surgical, } \\
\text { and trauma }\end{array}$ & $\mathrm{x}$ & $\mathrm{x}$ & & $\mathrm{x}$ & & $\mathrm{x}$ & $\mathrm{x}$ & $\begin{array}{l}\text { Oral suctioning, tooth brushing, } \\
\text { swabbing with a sponge toothette }\end{array}$ \\
\hline $\begin{array}{l}\text { Delghani } \\
\text { et } \mathrm{al}^{41}\end{array}$ & 2014 & Iran & BPS & NM & $50 \mathrm{TBI}$ & & $x$ & $x$ & & & & $x$ & $\begin{array}{l}\text { ET suctioning, eye care with } \\
\text { normal saline }\end{array}$ \\
\hline $\begin{array}{l}\text { Echegaray- } \\
\text { Benites } \\
\text { et a }\left.\right|^{91}\end{array}$ & 2014 & Canada & СРОТ & English & 43 brain surgery & $x$ & & & $x$ & & $x$ & $x$ & Turning, NIBP \\
\hline $\begin{array}{l}\text { Emsden } \\
\text { et } a^{63}\end{array}$ & 2019 & Switzerland & СРОТ & German & 60 medical and surgical & $x$ & & $x$ & $x$ & & $x$ & $x$ & Turning, gentle touch \\
\hline $\begin{array}{l}\text { Faritous } \\
\text { et a }\left.\right|^{86}\end{array}$ & 2016 & Iran & СРОТ & NM & 70 cardiac surgery & & $\mathrm{x}$ & & & & & $\mathrm{x}$ & Suctioning, changing position \\
\hline $\begin{array}{l}\text { Frandsen } \\
\text { et } \mathrm{al}^{61}\end{array}$ & 2016 & Denmark & СРОТ & Danish & 70 medical and surgical & $x$ & $\mathrm{x}$ & $\mathrm{x}$ & $\mathrm{x}$ & & $\mathrm{x}$ & $\mathrm{x}$ & Turning, arm wash \\
\hline $\begin{array}{l}\text { Gélinas } \\
\text { et al }{ }^{56}\end{array}$ & 2006 & Canada & СРОТ & French & 105 cardiac surgery & $\mathrm{x}$ & $x$ & & $x$ & & $\mathrm{x}$ & $\mathrm{x}$ & Positioning/turning \\
\hline $\begin{array}{l}\text { Gélinas et } \\
\text { al99 }^{99}\end{array}$ & 2009 & Canada & СРОТ & French & $\begin{array}{l}105 \text { cardiac surgery } \\
\text { (same as in Gélinas } \\
\text { et al }{ }^{56} \text { ) }\end{array}$ & $x$ & & & & & $x$ & & Turning \\
\hline $\begin{array}{l}\text { Gélinas et } \\
\mathrm{al}^{80}\end{array}$ & 2011 & Canada & СРОТ & French & $\begin{array}{l}9 \text { medical, surgical, and } \\
\text { trauma }\end{array}$ & & $x$ & & & & & $x$ & Turning, ET suctioning \\
\hline $\begin{array}{l}\text { Gélinas et } \\
\mathrm{al}^{59}\end{array}$ & 2015 & Canada & СРОТ & French & $\begin{array}{l}45 \text { medical, surgical, } \\
\text { and TBI }\end{array}$ & & $\mathrm{x}$ & & & & & $\mathrm{x}$ & Turning, NIBP \\
\hline $\begin{array}{l}\text { Gélinas and } \\
\text { Arbour }^{79}\end{array}$ & 2009 & Canada & СРОТ & $\begin{array}{l}\text { French and } \\
\text { English }\end{array}$ & $\begin{array}{l}257 \text { medical, surgical, } \\
\text { and trauma (58 new } \\
\text { patients) }\end{array}$ & $\mathrm{x}$ & $x$ & & & & $\mathrm{x}$ & $\mathrm{x}$ & Turning \\
\hline $\begin{array}{l}\text { Gélinas et } \\
\mathrm{al}^{l^{5}}\end{array}$ & 2009 & Canada & СРОТ & French & $\begin{array}{l}17 \text { clinicians (nurses } \\
\text { and physicians) }\end{array}$ & & & & & $x$ & & & \\
\hline $\begin{array}{l}\text { Gélinas and } \\
\text { Johnston }^{58}\end{array}$ & 2007 & Canada & СРОТ & English & $\begin{array}{l}55 \text { medical, surgical, } \\
\text { and trauma }\end{array}$ & $x$ & $x$ & & $x$ & & $x$ & $x$ & Turning, NIBP \\
\hline $\begin{array}{l}\text { Gélinas } \\
\text { et } \mathrm{al}^{14}\end{array}$ & 2017 & 28 countries & BPAT & $\begin{array}{l}\text { English and } \\
12 \text { other } \\
\text { languages }\end{array}$ & $\begin{array}{l}3851 \text { mixed } d x \\
192 \text { ICUs from } \\
28 \text { countries }\end{array}$ & $x$ & $x$ & & $\mathrm{x}$ & & $\mathrm{x}$ & $\mathrm{x}$ & $\begin{array}{l}12 \text { procedures: turning, ET suction- } \\
\text { ing, mobilization, respiratory } \\
\text { exercises, positioning, peripheral } \\
\text { blood draw, peripheral IV insertion, } \\
\text { wound care, ET suctioning, chest } \\
\text { tube removal, arterial line insertion, } \\
\text { wound drain removal }\end{array}$ \\
\hline
\end{tabular}




\begin{tabular}{|c|c|c|c|c|c|c|c|c|c|c|c|c|c|}
\hline Author & Year & Country & Tool & $\begin{array}{c}\text { Language } \\
\text { Version }\end{array}$ & ICU Clientele/Sample & $\begin{array}{l}\text { Able to } \\
\text { Self- } \\
\text { Report }\end{array}$ & $\begin{array}{l}\text { Unable } \\
\text { to Self- } \\
\text { Report }\end{array}$ & $\begin{array}{c}\text { Internal } \\
\text { Consist- } \\
\text { ency }\end{array}$ & $\begin{array}{l}\text { Interrater } \\
\text { Reliabil- } \\
\text { ity }\end{array}$ & $\begin{array}{l}\text { Content } \\
\text { Valida- } \\
\text { tion }\end{array}$ & $\begin{array}{l}\text { Criterion } \\
\text { Valida- } \\
\text { tion }\end{array}$ & $\begin{array}{l}\text { Discrimina- } \\
\text { tive } \\
\text { Validation }\end{array}$ & Procedure/Treatment \\
\hline $\begin{array}{l}\text { Ghanbari } \\
\text { et } \mathrm{al}^{87}\end{array}$ & 2016 & Iran & СРOT & NM & 150 cardiac surgery & $\mathrm{x}$ & & & & & $\mathrm{x}$ & & Suctioning \\
\hline $\begin{array}{l}\text { Gomarverdi } \\
\text { et } \mathrm{al}^{34}\end{array}$ & 2019 & Iran & $\begin{array}{l}\text { BPS } \\
\text { CPOT }\end{array}$ & NM & 90 (dx not specified) & & $x$ & & & & & $x$ & $\begin{array}{l}\text { Changing position, suctioning, } \\
\text { mouthwash, respiratory therapy }\end{array}$ \\
\hline $\begin{array}{l}\text { Gutysz- } \\
\text { Wojnicka } \\
\text { et al }{ }^{24} \\
\text { (in press) }\end{array}$ & 2018 & Poland & $\begin{array}{l}\text { BPS } \\
\text { NVPS }\end{array}$ & Polish & $\begin{array}{l}28 \text { medical, trauma, } \\
\text { and neurologic }\end{array}$ & & $x$ & $x$ & $x$ & $x$ & & $x$ & $\begin{array}{l}\text { ET suctioning or turning, NIPB or } \\
\text { dressing change }\end{array}$ \\
\hline $\begin{array}{l}\text { Hsiung } \\
\text { et } \mathrm{al}^{22}\end{array}$ & 2016 & Taiwan & $\begin{array}{l}\text { BPS } \\
\text { CPOT }\end{array}$ & $\begin{array}{l}\text { Chinese } \\
\text { Mandarin }\end{array}$ & 10 surgical & & $x$ & $x$ & & $x$ & & & ET suctioning \\
\hline $\begin{array}{l}\text { Hylén } \\
\text { et } \mathrm{al}^{25}\end{array}$ & 2016 & Sweden & $\begin{array}{l}\text { BPS } \\
\text { BPS-NI }\end{array}$ & Swedish & $\begin{array}{l}20 \text { medical, surgical, } \\
\text { and trauma }\end{array}$ & & $\mathrm{x}$ & & $\mathrm{x}$ & $\mathrm{x}$ & & $\mathrm{x}$ & Repositioning \\
\hline $\begin{array}{l}\text { Jendoubi } \\
\text { et } \mathrm{al}^{42}\end{array}$ & 2017 & Tunisia & $\begin{array}{l}\text { BPSC- } \\
\text { POT }\end{array}$ & NM & $21 \mathrm{TBI}$ & & $x$ & & & & & $x$ & ET suctioning \\
\hline $\begin{array}{l}\text { Joffe } \\
\text { et } \mathrm{al}^{92}\end{array}$ & 2016 & $\begin{array}{l}\text { United } \\
\text { States }\end{array}$ & СРОТ & English & 79 with brain injury & $\mathrm{x}$ & $\mathrm{x}$ & & $\mathrm{x}$ & & $x$ & $\mathrm{x}$ & Turning, gentle touch \\
\hline $\begin{array}{l}\text { Juarez } \\
\text { et } \mathrm{al}^{35} \\
\end{array}$ & 2010 & $\begin{array}{l}\text { United } \\
\text { States }\end{array}$ & $\begin{array}{l}\text { BPS } \\
\text { NVPS-R }\end{array}$ & English & $\begin{array}{l}200 \text { medical and } \\
\text { surgical }\end{array}$ & & $\mathrm{x}$ & $\mathrm{x}$ & $\mathrm{x}$ & & & $\mathrm{x}$ & Turning \\
\hline $\begin{array}{l}\text { Kabes } \\
\text { et al }{ }^{117}\end{array}$ & 2009 & $\begin{array}{l}\text { United } \\
\text { States }\end{array}$ & $\begin{array}{l}\text { NVPS } \\
\text { NVPS-R }\end{array}$ & English & 64 surgical and trauma & & $x$ & $x$ & $x$ & & & $x$ & Suctioning or repositioning \\
\hline $\begin{array}{l}\text { Kanji } \\
\text { et } \mathrm{al}^{81}\end{array}$ & 2016 & Canada & СРОТ & English & $\begin{array}{l}40 \text { medical and surgical } \\
\text { with delirium }\end{array}$ & & $\mathrm{x}$ & $\mathrm{x}$ & $\mathrm{x}$ & & & $\mathrm{x}$ & $\begin{array}{l}\text { Repositioning, ET suctioning, } \\
\text { wound dressing change, NIBP }\end{array}$ \\
\hline $\begin{array}{r}\text { Kaya and } \\
\text { Erden }^{118} \\
\end{array}$ & 2019 & Turkey & NVPS-R & Turkish & 74 surgical & & $x$ & $x$ & & $x$ & & & ET suctioning \\
\hline Keane $^{88}$ & 2013 & $\begin{array}{l}\text { United } \\
\text { States }\end{array}$ & СРOT & English & 21 cardiac surgery & $x$ & & & $x$ & & $x$ & $x$ & Positioning \\
\hline $\begin{array}{l}\text { Khanna } \\
\text { et al }{ }^{82}\end{array}$ & 2018 & India & СPOT & NM & 60 medical and surgical & & $x$ & & & & & $x$ & Positioning, ET suctioning \\
\hline $\begin{array}{l}\text { Kiavar } \\
\text { et al }{ }^{99} \\
\end{array}$ & 2016 & Iran & СРОТ & NM & 91 cardiac surgery & & $\mathrm{x}$ & & & & & $\mathrm{x}$ & ET suctioning, changing position \\
\hline $\begin{array}{l}\text { Klein } \\
\text { et } \mathrm{al}^{115}\end{array}$ & 2010 & $\begin{array}{l}\text { United } \\
\text { States }\end{array}$ & NPAT & English & $\begin{array}{l}220 \text { medical and } \\
\text { surgical }\end{array}$ & & & $x$ & $\mathrm{x}$ & $\mathrm{x}$ & $x$ & & \\
\hline $\begin{array}{l}\text { Klein } \\
\text { et } \mathrm{al}^{18}\end{array}$ & 2018 & Brazil & $\begin{array}{l}\text { BPS } \\
\text { BPS-NI } \\
\text { CPOT }\end{array}$ & $\begin{array}{l}\text { Brazilian } \\
\text { Portuguese }\end{array}$ & $\begin{array}{l}168 \text { medical and } \\
\text { surgical }\end{array}$ & & $x$ & & $x$ & & & $x$ & $\begin{array}{l}\text { Turning, standardized stimulation } \\
\text { by pressure algometry }\end{array}$ \\
\hline $\begin{array}{l}\text { Kotfis } \\
\text { et al }{ }^{68}\end{array}$ & 2018 & Poland & СРОТ & Polish & 71 medical and surgical & $x$ & $x$ & & $x$ & & $x$ & $x$ & $\begin{array}{l}\text { Positioning and turning, eyelid } \\
\text { wiping with normal saline }\end{array}$ \\
\hline $\begin{array}{l}\text { Kwak } \\
\text { et al }{ }^{66}\end{array}$ & 2012 & Korea & СРОТ & Korean & $\begin{array}{l}202 \text { medical, surgical, } \\
\text { and trauma }\end{array}$ & $x$ & $\mathrm{x}$ & & $\mathrm{x}$ & & $\mathrm{x}$ & $\mathrm{x}$ & Suctioning \\
\hline $\begin{array}{l}\text { Latorre- } \\
\text { Marco } \\
\text { et al }{ }^{110} \\
\end{array}$ & 2011 & Spain & ESCID & Spanish & $\begin{array}{l}42 \text { mixed (medical, } \\
\text { surgical, trauma, } \\
\text { neurological) }\end{array}$ & & $\mathrm{x}$ & $x$ & $\mathrm{x}$ & $\mathrm{x}$ & & $x$ & \\
\hline $\begin{array}{l}\text { Latorre- } \\
\text { Marco } \\
\text { et al }\left.\right|^{113}\end{array}$ & 2016 & Spain & ESCID & Spanish & $\begin{array}{l}190 \text { mixed (medical, } \\
\text { surgical, trauma, } \\
\text { neurological) }\end{array}$ & & $x$ & $\mathrm{x}$ & $\mathrm{x}$ & & & $\mathrm{x}$ & $\begin{array}{l}\text { Turning/repositioning, ET } \\
\text { suctioning, gentle rubbing of a } \\
\text { gauze cloth on intact skin }\end{array}$ \\
\hline
\end{tabular}




\begin{tabular}{|c|c|c|c|c|c|c|c|c|c|c|c|c|c|}
\hline Author & Year & Country & Tool & $\begin{array}{c}\text { Language } \\
\text { Version }\end{array}$ & ICU Clientele/Sample & $\begin{array}{l}\text { Able to } \\
\text { Self- } \\
\text { Report }\end{array}$ & $\begin{array}{l}\text { Unable } \\
\text { to Self- } \\
\text { Report }\end{array}$ & $\begin{array}{c}\text { Internal } \\
\text { Consist- } \\
\text { ency }\end{array}$ & $\begin{array}{c}\text { Interrater } \\
\text { Reliabil- } \\
\text { ity }\end{array}$ & $\begin{array}{l}\text { Content } \\
\text { Valida- } \\
\text { tion }\end{array}$ & $\begin{array}{l}\text { Criterion } \\
\text { Valida- } \\
\text { tion }\end{array}$ & $\begin{array}{l}\text { Discrimina- } \\
\text { tive } \\
\text { Validation }\end{array}$ & Procedure/Treatment \\
\hline $\begin{array}{l}\text { Lee } \\
\text { et } \mathrm{al}^{93}\end{array}$ & 2013 & Korea & СРOT & NM & $\begin{array}{l}31 \text { with brain injury and } \\
\text { brain surgery }\end{array}$ & & $x$ & & & & & $x$ & ET suctioning \\
\hline $\begin{array}{l}\mathrm{Li} \\
\mathrm{et} \mathrm{al}^{13}\end{array}$ & 2009 & $\begin{array}{l}\text { United } \\
\text { States }\end{array}$ & BOT & English & 48 cardiac surgery & & $x$ & & & & & $x$ & $\begin{array}{l}\text { ET suctioning or turning, gentle } \\
\text { touch }\end{array}$ \\
\hline Li et $\mathrm{al}^{75}$ & 2014 & China & СРОТ & Chinese & 63 medical and surgical & $\mathrm{x}$ & & $\mathrm{x}$ & $x$ & & $\mathrm{x}$ & $x$ & Turning, NIBP \\
\hline $\begin{array}{l}\text { Linde } \\
\text { et al }{ }^{90}\end{array}$ & 2013 & $\begin{array}{l}\text { United } \\
\text { States }\end{array}$ & СРОТ & English & 30 cardiac surgery & $x$ & $x$ & & $x$ & & & $x$ & $\begin{array}{l}\text { Turning, ET suctioning, } \\
\text { compression stocking, central } \\
\text { catheter dressing change }\end{array}$ \\
\hline $\begin{array}{l}\text { Liu } \\
\text { et } \mathrm{al}^{47}\end{array}$ & 2015 & China & $\begin{array}{l}\text { BPS } \\
\text { BPS-NI } \\
\text { CPOT }\end{array}$ & Chinese & $\begin{array}{l}117 \text { medical and } \\
\text { surgical }\end{array}$ & & $x$ & $x$ & $x$ & & & $x$ & Suctioning, NIBP \\
\hline $\begin{array}{l}\text { Lopez-Lopez } \\
\text { et } \mathrm{al}^{114}\end{array}$ & 2018 & Spain & ESCID & Spanish & 124 trauma & & $\mathrm{x}$ & & $\mathrm{x}$ & & & $\mathrm{x}$ & $\begin{array}{l}\text { Mobilization, ET suctioning, gentle } \\
\text { rubbing of a gauze cloth on intact } \\
\text { skin }\end{array}$ \\
\hline $\begin{array}{l}\text { Navarro- } \\
\text { Colom } \\
\text { et al }{ }^{39}\end{array}$ & 2015 & Spain & BPS & NM & 34 medical and surgical & & $\mathrm{x}$ & $\mathrm{x}$ & $\mathrm{x}$ & & & & Mobilization \\
\hline $\begin{array}{l}\text { Nürnberg } \\
\text { et al }\end{array}$ & 2011 & Sweden & СРОТ & Swedish & 40 medical and surgical & & $x$ & $x$ & $x$ & & & $x$ & Turning, arm/face wash \\
\hline $\begin{array}{r}\text { Odhner } \\
\text { et al }{ }^{116}\end{array}$ & 2003 & $\begin{array}{l}\text { United } \\
\text { States }\end{array}$ & $\begin{array}{l}\text { FLACC } \\
\text { NVPS }\end{array}$ & English & $\begin{array}{l}59 \text { burn, surgical, and } \\
\text { trauma }\end{array}$ & & $x$ & $x$ & $x$ & & & & Turning or suctioning \\
\hline $\begin{array}{l}\text { Olsen } \\
\text { et } \mathrm{al}^{23}\end{array}$ & 2015 & Norway & $\begin{array}{l}\text { BPS } \\
\text { BPS-NI }\end{array}$ & Norwegian & $111(\mathrm{dx}$ not specified) & & $\mathrm{x}$ & & $\begin{array}{c}x \\
n=11\end{array}$ & & & $\mathrm{x}$ & Turning \\
\hline $\begin{array}{l}\text { Paulson- } \\
\text { Conger } \\
\text { et al }{ }^{83}\end{array}$ & 2011 & $\begin{array}{l}\text { United } \\
\text { States }\end{array}$ & $\begin{array}{l}\text { CPOT } \\
\text { PAINAD }\end{array}$ & English & 100 medical & & $x$ & $x$ & & & & & \\
\hline $\begin{array}{l}\text { Payen } \\
\text { et } \mathrm{al}^{16}\end{array}$ & 2001 & France & BPS & French & 30 surgical and trauma & & $\mathrm{x}$ & & $\mathrm{x}$ & & & $\mathrm{x}$ & $\begin{array}{l}\text { Mobilization, central venous } \\
\text { catheter dressing change }\end{array}$ \\
\hline $\begin{array}{l}\text { Puntillo } \\
\text { et al }{ }^{12}\end{array}$ & 1997 & $\begin{array}{l}\text { United } \\
\text { States }\end{array}$ & PAIN & English & 31 surgical & $x$ & & & & $x$ & & & \\
\hline $\begin{array}{l}\text { Puntillo } \\
\text { et } \text { al }^{10}\end{array}$ & 2004 & $\begin{array}{l}\text { United } \\
\text { States, } \\
\text { Canada, } \\
\text { Australia }\end{array}$ & BOT & English & $\begin{array}{l}5957 \text { mixed (medical, } \\
\text { surgical, trauma, burn, } \\
\text { other); } 169 \text { sites from } \\
4 \text { countries (United } \\
\text { States, Canada, Aus- } \\
\text { tralia, and United } \\
\text { Kingdom) }\end{array}$ & $\mathrm{x}$ & & & & & $\mathrm{x}$ & $\mathrm{x}$ & $\begin{array}{l}\text { Femoral sheath removal, central } \\
\text { venous catheter placement, ET } \\
\text { suctioning, wound care, wound } \\
\text { drain removal, turning }\end{array}$ \\
\hline $\begin{array}{l}\text { Rahu } \\
\text { et } \mathrm{al}^{36}\end{array}$ & 2015 & $\begin{array}{l}\text { United } \\
\text { States }\end{array}$ & $\begin{array}{l}\text { BPS } \\
\text { FLACC } \\
\text { NVPS }\end{array}$ & English & 150 medical and trauma & $x$ & $\mathrm{x}$ & & $x$ & & $x$ & $x$ & ET suctioning, physical examination \\
\hline $\begin{array}{l}\text { Ribeiro } \\
\text { et } \mathrm{al}^{43}\end{array}$ & 2017 & Brazil & BPS & $\begin{array}{l}\text { Brazilian } \\
\text { (Azevedo) }\end{array}$ & $20 \mathrm{TBI}$ & & $\mathrm{x}$ & & & & & $x$ & ET suctioning, eye cleaning \\
\hline \multirow[t]{2}{*}{$\begin{array}{l}\text { Ribeiro } \\
\text { et } \text { al }^{44}\end{array}$} & 2018 & Brazil & BPS & Brazilian & $27 \mathrm{TBI}$ & & $x$ & & $x$ & & & $x$ & ET suctioning, eye cleaning \\
\hline & & & & & & & & & & & & \multicolumn{2}{|r|}{ Continueo } \\
\hline
\end{tabular}




\begin{tabular}{|c|c|c|c|c|c|c|c|c|c|c|c|c|c|}
\hline Author & Year & Country & Tool & $\begin{array}{c}\text { Language } \\
\text { Version }\end{array}$ & ICU Clientele/Sample & $\begin{array}{l}\text { Able to } \\
\text { Self- } \\
\text { Report }\end{array}$ & $\begin{array}{l}\text { Unable } \\
\text { to Self- } \\
\text { Report }\end{array}$ & $\begin{array}{c}\text { Internal } \\
\text { Consist- } \\
\text { ency }\end{array}$ & $\begin{array}{l}\text { Interrater } \\
\text { Reliabil- } \\
\text { ity }\end{array}$ & $\begin{array}{l}\text { Content } \\
\text { Valida- } \\
\text { tion }\end{array}$ & $\begin{array}{l}\text { Criterion } \\
\text { Valida- } \\
\text { tion }\end{array}$ & $\begin{array}{l}\text { Discrimina- } \\
\text { tive } \\
\text { Validation }\end{array}$ & Procedure/Treatment \\
\hline $\begin{array}{l}\text { Ribeiro } \\
\text { et } \text { a }^{45}\end{array}$ & 2019 & Brazil & BPS & Brazilian & $\begin{array}{l}37 \text { TBI (including the } 27 \\
\text { patients in } 2018 \text { study) }\end{array}$ & & $\mathrm{x}$ & $\mathrm{x}$ & $\mathrm{x}$ & & & $\mathrm{x}$ & ET suctioning, eye cleaning \\
\hline $\begin{array}{l}\text { Rijkenberg } \\
\text { et al }{ }^{19}\end{array}$ & 2015 & Netherlands & $\begin{array}{l}\text { BPS } \\
\text { CPOT }\end{array}$ & Dutch & 68 medical & & $x$ & $x$ & $x$ & & & $x$ & Turning, oral care \\
\hline $\begin{array}{l}\text { Rijkenberg } \\
\text { et } \mathrm{al}^{48}\end{array}$ & 2017 & Netherlands & $\begin{array}{l}\text { BPS } \\
\text { CPOT }\end{array}$ & Dutch & 72 cardiac surgery & & $\mathrm{x}$ & $x$ & $\mathrm{x}$ & & & $\mathrm{x}$ & Turning, oral care \\
\hline $\begin{array}{l}\text { Ross } \\
\text { et } \mathrm{al}^{84}\end{array}$ & 2016 & Canada & СРОТ & English & $\begin{array}{l}22 \text { medical } \\
\text { (at high risk of dying) }\end{array}$ & & $\mathrm{x}$ & & $\mathrm{x}$ & & & $\mathrm{x}$ & Turning, gentle touch \\
\hline $\begin{array}{l}\text { Severgnini } \\
\text { et } \mathrm{al}^{37}\end{array}$ & 2016 & Italy & $\begin{array}{l}\text { BPS } \\
\text { CPOT }\end{array}$ & NM & $\begin{array}{l}101 \text { medical and } \\
\text { surgical }\end{array}$ & $x$ & $x$ & & & & $x$ & $x$ & $\begin{array}{l}\text { ET suctioning, peripheral venous } \\
\text { cannulation }\end{array}$ \\
\hline Shan et $\mathrm{al}^{94}$ & 2018 & China & СРОТ & Chinese & 400 with brain injury & $x$ & $x$ & & $\mathrm{x}$ & & $\mathrm{x}$ & $\mathrm{x}$ & Suctioning, gentle touch \\
\hline $\begin{array}{l}\text { Stilma } \\
\text { et al }{ }^{62}\end{array}$ & 2015 & Netherlands & СРОТ & Dutch & $\begin{array}{l}108 \text { medical and } \\
\text { surgical }\end{array}$ & $\mathrm{x}$ & $\mathrm{x}$ & $\mathrm{x}$ & $\mathrm{x}$ & & $\mathrm{x}$ & $x$ & Turning \\
\hline $\begin{array}{l}\text { Sulla } \\
\text { et a }\left.\right|^{95}\end{array}$ & 2017 & Italy & $\begin{array}{l}\text { CPOT } \\
\text { PAINAD }\end{array}$ & Italian & 50 with brain injury & $x$ & $\mathrm{x}$ & $\mathrm{x}$ & $\mathrm{x}$ & & $\mathrm{x}$ & $\mathrm{x}$ & Mobilization for hygiene \\
\hline $\begin{array}{l}\text { Storsveen } \\
\text { and } \\
\text { Hall-Lord }^{74}\end{array}$ & 2016 & Norway & СРОТ & Norwegian & $\begin{array}{l}18 \text { medical and surgical } \\
\text { (including } \\
\text { neurological) }\end{array}$ & & $\mathrm{x}$ & & $\mathrm{x}$ & & & $\mathrm{x}$ & Turning \\
\hline $\begin{array}{l}\text { Topolovec- } \\
\text { Vranic et } \mathbf{a}^{96}\end{array}$ & 2013 & Canada & $\begin{array}{l}\text { CPOT } \\
\text { NVPS-R }\end{array}$ & English & $\begin{array}{l}66 \text { neurocritically ill (TBI } \\
\text { or neurologic disorder) }\end{array}$ & $x$ & $\mathrm{x}$ & & $\mathrm{x}$ & & $\mathrm{x}$ & $\mathrm{x}$ & Turning, NIBP \\
\hline $\begin{array}{l}\text { Vazquez } \\
\text { et } \mathrm{al}^{71}\end{array}$ & 2011 & Spain & СРОТ & Spanish & 96 medical and surgical & $\begin{array}{l}\text { Con- } \\
\text { scious }\end{array}$ & $\mathrm{x}$ & & $\mathrm{x}$ & & & $\mathrm{x}$ & Positioning \\
\hline $\begin{array}{l}\text { Voepel- } \\
\text { Lewis } \\
\text { et al }{ }^{124} \\
\end{array}$ & 2010 & $\begin{array}{l}\text { United } \\
\text { States }\end{array}$ & FLACC & English & $\begin{array}{l}29 \text { medical and surgical } \\
\text { (including neurologi- } \\
\text { cal/neurosurgical) }\end{array}$ & & $\mathrm{x}$ & $\mathrm{x}$ & $\mathrm{x}$ & & & $\mathrm{x}$ & $\begin{array}{l}\text { Turning or suctioning, analgesic } \\
\text { administration }\end{array}$ \\
\hline $\begin{array}{l}\text { Wiegand } \\
\text { et } \mathrm{al}^{126}\end{array}$ & 2018 & $\begin{array}{l}\text { United } \\
\text { States }\end{array}$ & MOPAT & English & 27 medical & & $x$ & $x$ & $x$ & & & $x$ & $\begin{array}{l}\text { Turning, suctioning, dressing } \\
\text { change, arterial catheter insertion }\end{array}$ \\
\hline $\begin{array}{l}\text { Young } \\
\text { et }\left.\right|^{38}\end{array}$ & 2006 & Australia & BPS & English & $\begin{array}{l}44 \text { medical, surgical, } \\
\text { and neurological }\end{array}$ & & $\mathrm{x}$ & $\mathrm{x}$ & $\mathrm{x}$ & & & $\mathrm{x}$ & $\begin{array}{l}\text { Repositioning, eye wash with } \\
\text { normal saline }\end{array}$ \\
\hline
\end{tabular}

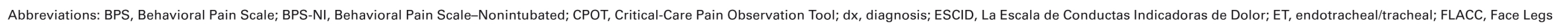

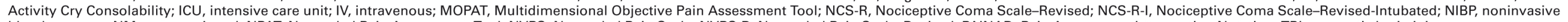

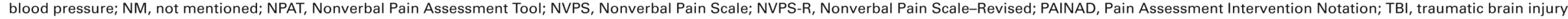


Table 3: Description of Feasibility and Implementation Studies $(\mathbf{n}=\mathbf{2 5})$

\begin{tabular}{|c|c|c|c|c|c|c|c|c|c|c|c|}
\hline Author & Year & Country & Tool & $\begin{array}{l}\text { Language } \\
\text { Version }\end{array}$ & Design & ICU Setting & Sample & Feasibility & $\begin{array}{c}\text { Clinical } \\
\text { Relevance }\end{array}$ & Practice Indicators & Patient Outcomes \\
\hline $\begin{array}{l}\text { Arbour } \\
\text { et al }{ }^{109}\end{array}$ & 2011 & Canada & СРОТ & French & Pre/post & $\begin{array}{l}\text { Medical, surgical, } \\
\text { trauma }\end{array}$ & $\begin{array}{l}\text { Patients with trauma: } \\
15 \text { pre, } 15 \text { post }\end{array}$ & & & $\begin{array}{l}\text { Frequency of pain assessments, } \\
\text { No. pain episodes, administra- } \\
\text { tion of analgesics, effectiveness } \\
\text { of analgesia }\end{array}$ & $\begin{array}{l}\text { MV duration, ICU length } \\
\text { of stay, No. of } \\
\text { complications }\end{array}$ \\
\hline $\begin{array}{l}\text { Asadi- } \\
\text { Noghabi } \\
\text { et al }{ }^{102}\end{array}$ & 2015 & Iran & СPOT & NM & Pre/post & NM & 106 ICU nurses & $x$ & $x$ & & \\
\hline $\begin{array}{l}\text { Bernard } \\
\text { et al } \mathrm{l}^{40, a} \\
\text { (in press) }\end{array}$ & 2019 & France & BPS & French & $\begin{array}{l}\text { Descriptive, } \\
\text { post }\end{array}$ & $\begin{array}{l}\text { Medical, surgical, } \\
\text { neurologic ICU }\end{array}$ & 15 nurses & $\mathrm{x}$ & $\mathrm{x}$ & & \\
\hline $\begin{array}{l}\text { Bourbonnais } \\
\text { et al }{ }^{100}\end{array}$ & 2016 & Canada & СРОТ & English & $\begin{array}{l}\text { Descriptive, } \\
\text { post }\end{array}$ & $\begin{array}{l}\text { Medical, surgical, } \\
\text { trauma }\end{array}$ & $\begin{array}{l}23 \text { ICU nurses who eval- } \\
\text { uated patients } 5 \text { times } \\
\text { ( } n=115 \text { assessments) }\end{array}$ & $\mathrm{x}$ & $x$ & $\begin{array}{l}\text { Frequency of CPOT documenta- } \\
\text { tion, No. of pain episodes, } \\
\text { analgesia and sedation, non- } \\
\text { pharmacologic interventions }\end{array}$ & \\
\hline $\begin{array}{l}\text { Chanques } \\
\text { et al }{ }^{49}\end{array}$ & 2006 & France & BPS & French & Pre/post & Medical, surgical & $\begin{array}{l}\text { Patients: } 100 \text { pre, } \\
130 \text { post } \\
\text { Nurses: } 25 \text { pre, } \\
32 \text { post }\end{array}$ & $\mathrm{x}$ & $x$ & $\begin{array}{l}\text { Frequency of pain and agitation } \\
\text { assessments, administration of } \\
\text { analgesics and sedatives }\end{array}$ & $\begin{array}{l}\text { Incidence of pain and } \\
\text { agitation, ICU length of } \\
\text { stay, MV duration, } \\
\text { adverse events, noso- } \\
\text { comial infection }\end{array}$ \\
\hline $\begin{array}{l}\text { Chanques } \\
\text { et al } \mathrm{al}^{46, \mathrm{a}}\end{array}$ & 2014 & $\begin{array}{l}\text { United } \\
\text { States }\end{array}$ & $\begin{array}{c}\text { BPS } \\
\text { BPS-NI } \\
\text { CPOT } \\
\text { NVPS-R }\end{array}$ & English & $\begin{array}{l}\text { Descriptive, } \\
\text { post }\end{array}$ & Medical & 20 nurses & $x$ & $x$ & & \\
\hline $\begin{array}{l}\text { Damico } \\
\text { et al }{ }^{103}\end{array}$ & 2018 & Italy & СРОТ & Italian & Pre/post & $\begin{array}{l}\text { Medical, surgical, } \\
\text { trauma }\end{array}$ & 370 pre/217 post & & & $\begin{array}{l}\text { CPOT scores, administration of } \\
\text { analgesia and sedation }\end{array}$ & Memory of pain \\
\hline $\begin{array}{l}\text { De Jong } \\
\text { et } \mathrm{al}^{\mathrm{5}^{2}}\end{array}$ & 2013 & France & $\begin{array}{l}\text { BPS/ } \\
\text { BPS-NI }\end{array}$ & French & Ol project & Medical, surgical & 193 patients & & & $\begin{array}{l}\text { Analgesic ordering practice, use } \\
\text { of nonpharmacologic } \\
\text { interventions }\end{array}$ & $\begin{array}{l}\text { Incidence of severe pain, } \\
\text { incidence of serious } \\
\text { adverse events }{ }^{b}\end{array}$ \\
\hline $\begin{array}{l}\text { Faust } \\
\text { et al }{ }^{108}\end{array}$ & 2016 & $\begin{array}{l}\text { United } \\
\text { States }\end{array}$ & СРОТ & English & Pre/post & Medical & 65 pre, 79 post & & & $\begin{array}{l}\text { Pain and sedation scores, admin- } \\
\text { istration of analgesics and } \\
\text { sedatives }\end{array}$ & $\begin{array}{l}\text { MV duration, ICU length } \\
\text { of stay, self-extubation, } \\
\text { death }\end{array}$ \\
\hline Gélinas $^{60}$ & 2010 & Canada & CPOT & English & $\begin{array}{c}\text { Descriptive, } \\
\text { post }\end{array}$ & $\begin{array}{l}\text { Medical, surgical, } \\
\text { trauma }\end{array}$ & $33 \mathrm{ICU}$ nurses & $x$ & $x$ & & \\
\hline $\begin{array}{l}\text { Gélinas } \\
\text { et al }{ }^{104}\end{array}$ & 2011 & Canada & СРOT & French & Pre/post & $\begin{array}{l}\text { Medical, surgical, } \\
\text { trauma }\end{array}$ & $\begin{array}{l}90 \text { patients with various } \\
\mathrm{dx:} 30 \text { pre, } 30 \text { at } 3 \\
\text { months, and } 30 \text { at } 12 \\
\text { months post }\end{array}$ & & & $\begin{array}{l}\text { Frequency of pain assessments, } \\
\text { administration of analgesia and } \\
\text { sedation, effectiveness of } \\
\text { analgesia }\end{array}$ & \\
\hline $\begin{array}{r}\text { Gélinas } \\
\text { et al }{ }^{101}\end{array}$ & 2014 & Canada & СРОТ & French & $\begin{array}{c}\text { Descriptive, } \\
\text { post }\end{array}$ & $\begin{array}{l}\text { Medical, surgical, } \\
\text { trauma }\end{array}$ & 38 nurses & $\mathrm{x}$ & $\mathrm{x}$ & & \\
\hline $\begin{array}{l}\text { Gélinas } \\
\text { et al }\left.\right|^{59, a}\end{array}$ & 2015 & Canada & СРОТ & French & $\begin{array}{c}\text { Descriptive, } \\
\text { post }\end{array}$ & $\begin{array}{l}\text { Medical, surgical, } \\
\text { trauma }\end{array}$ & 35 nurses & $\mathrm{x}$ & $\mathrm{x}$ & & \\
\hline $\begin{array}{l}\text { Mascaren- } \\
\text { has et al }{ }^{106}\end{array}$ & 2018 & $\begin{array}{l}\text { United } \\
\text { Kingdom }\end{array}$ & СРОТ & English & Ol project & General ICU & $\begin{array}{l}\text { Observations and chart } \\
\text { reviews }\end{array}$ & & & $\begin{array}{l}\text { Assess pain every } 4 \text { hours, treat } \\
\text { pain when CPOT }>3\end{array}$ & $\begin{array}{l}\text { Measured but not } \\
\text { reported }\end{array}$ \\
\hline $\begin{array}{l}\text { Olsen } \\
\text { et al }{ }^{53}\end{array}$ & 2015 & Norway & $\begin{array}{l}\text { BPS } \\
\text { BPS-NI }\end{array}$ & Norwegian & $\begin{array}{l}\text { Descriptive, } \\
\text { post }\end{array}$ & $\begin{array}{l}2 \text { ICUs (medical and } \\
\text { surgical) and } 1 \\
\text { PACU }\end{array}$ & 217 nurses & & & $\begin{array}{l}\text { Nurses' adherence to use of } \\
\text { tools and pain management } \\
\text { algorithm }\end{array}$ & \\
\hline
\end{tabular}




\section{Table 3:Continued}

\begin{tabular}{|c|c|c|c|c|c|c|c|c|c|c|c|}
\hline Author & Year & Country & Tool & $\begin{array}{c}\text { Language } \\
\text { version }\end{array}$ & Design & ICU Setting & Sample & Feasibility & $\begin{array}{c}\text { Clinical } \\
\text { Relevance }\end{array}$ & Practice Indicators & Patient Outcomes \\
\hline $\begin{array}{l}\text { Olsen } \\
\text { et } \mathrm{al}^{54}\end{array}$ & 2016 & Norway & $\begin{array}{l}\text { BPS } \\
\text { BPS-NI }\end{array}$ & Norwegian & Pre/post & $\begin{array}{l}2 \text { ICUs (medical and } \\
\text { surgical) and } 1 \\
\text { PACU }\end{array}$ & 398 pre, 252 post & & & $\begin{array}{l}\text { Frequency of pain assessments, } \\
\text { administration of analgesics } \\
\text { and sedatives }\end{array}$ & $\begin{array}{l}\text { ICU length of stay, MV } \\
\text { duration }\end{array}$ \\
\hline $\begin{array}{l}\text { Payen } \\
\text { et al }\left.\right|^{16, a}\end{array}$ & 2001 & France & BPS & French & $\begin{array}{l}\text { Descriptive, } \\
\text { post }\end{array}$ & Trauma, surgical & $\begin{array}{l}28 \text { evaluators (nurses, } \\
\text { nurse's aides, physi- } \\
\text { cian, physical } \\
\text { therapist) }\end{array}$ & $x$ & $x$ & & \\
\hline $\begin{array}{l}\text { Phillips } \\
\text { et al }{ }^{105} \\
\text { (in press) }\end{array}$ & 2018 & Australia & CPOT & English & Pre/post & $\begin{array}{l}\text { Medical, surgical, } \\
\text { trauma }\end{array}$ & $\begin{array}{l}\text { Medical and trauma } \\
\text { patients: } 441 \text { pre, } 344 \\
\text { post }\end{array}$ & & & $\begin{array}{l}\text { Frequency of pain assessments, } \\
\text { administration of analgesia and } \\
\text { sedation }\end{array}$ & \\
\hline $\begin{array}{l}\text { Puntillo } \\
\text { et al }\left.\right|^{122}\end{array}$ & 2002 & $\begin{array}{l}\text { United } \\
\text { States }\end{array}$ & PAIN & English & $\begin{array}{l}\text { Descriptive, } \\
\text { post }\end{array}$ & 3 ICUs and 2 PACUs & 11 nurses & $\mathrm{x}$ & $\mathrm{x}$ & & \\
\hline $\begin{array}{l}\text { Radtke } \\
\text { et al }{ }^{50}\end{array}$ & 2012 & Germany & BPS & NM & $\begin{array}{l}\text { Experimental, } \\
\text { no } \\
\text { randomization }\end{array}$ & $\begin{array}{c}\text { Types of ICUs }(n=3) \\
\text { not specified }\end{array}$ & 619 patients & & & Frequency of pain assessments & $\begin{array}{l}\text { ICU length of stay, MV } \\
\text { duration, mortality }\end{array}$ \\
\hline $\begin{array}{l}\text { Rose } \\
\text { et al }{ }^{107}\end{array}$ & 2013 & Canada & СPOT & English & Pre/post & $\begin{array}{l}\text { Medical, surgical, } \\
\text { trauma; } \\
\text { cardiovascular }\end{array}$ & 130 pre, 132 post & & & $\begin{array}{l}\text { Frequency of pain assessments, } \\
\text { administration of analgesics } \\
\text { and sedatives }\end{array}$ & \\
\hline $\begin{array}{l}\text { Sacco } \\
\text { et al }{ }^{121}\end{array}$ & 2016 & $\begin{array}{l}\text { United } \\
\text { States }\end{array}$ & NVPS-I & English & Pre/post & Trauma & $\begin{array}{l}\text { Patients: } 95 \text { pre, } 145 \\
\text { post } \\
\text { Nurses: } 27 \\
\text { (satisfaction with pro- } \\
\text { tocol use) }\end{array}$ & $x$ & $x$ & $\begin{array}{l}\text { ICU nurse responsive to pain, } \\
\text { administration of analgesics } \\
\text { and antipsychotics }\end{array}$ & $\begin{array}{l}\text { ICU length of stay, MV } \\
\text { duration }\end{array}$ \\
\hline $\begin{array}{l}\text { Topolovec- } \\
\text { Vranic } \\
\text { et al }{ }^{120}\end{array}$ & 2010 & Canada & NVPS-I & English & Pre/post & $\begin{array}{l}\text { Neurological, } \\
\text { trauma }\end{array}$ & $\begin{array}{l}\text { Patient surveys: } 20 \text { pre, } \\
32 \text { post } \\
\text { Charts: } 36 \text { pre, } 36 \text { post } \\
\text { Nurse surveys: } 53 \text { pre, } \\
32 \text { post }\end{array}$ & $\mathrm{x}$ & $\mathrm{x}$ & $\begin{array}{l}\text { Frequency of pain assessments, } \\
\text { administration of opioids, Staff } \\
\text { Satisfaction Questionnaire } \\
\text { (ease of use, satisfaction and } \\
\text { confidence with pain assess- } \\
\text { ment /management, barriers) }\end{array}$ & $\begin{array}{l}\text { Patient Outcome Ques- } \\
\text { tionnaire (pain inten- } \\
\text { sity, satisfaction with } \\
\text { pain management) }\end{array}$ \\
\hline $\begin{array}{l}\text { Topolovec- } \\
\text { Vranic } \\
\text { et al } l^{96, a}\end{array}$ & 2013 & Canada & $\begin{array}{l}\text { CPOT } \\
\text { NVPS-R }\end{array}$ & English & $\begin{array}{c}\text { Descriptive, } \\
\text { post }\end{array}$ & Descriptive, post & $\begin{array}{l}20 \text { nurses: } 10 \text { for each } \\
\text { scale }\end{array}$ & $\mathrm{x}$ & $x$ & & \\
\hline $\begin{array}{l}\text { Williams } \\
\text { et a }\left.\right|^{51}\end{array}$ & 2008 & Australia & BPS & English & Pre/post & General, mixed & 369 pre, 400 post & & & $\begin{array}{l}\text { Administration of analgesics } \\
\text { and sedatives }\end{array}$ & $\begin{array}{l}\text { ICU length of stay, MV } \\
\text { duration, adverse events }\end{array}$ \\
\hline
\end{tabular}

